\title{
Streamflow Characteristics for Selected Stations In and Near the Grand Mesa, Uncompahgre, and Gunnison National Forests, Southwestern Colorado
}

By Gerhard Kuhn

U.S. GEOLOGICAL SURVEY

Open-File Report 02-471

Prepared in cooperation with the

GRAND MESA, UNCOMPAHGRE, and GUNNISON NATIONAL FORESTS 


\title{
U.S. DEPARTMENT OF THE INTERIOR GALE A. NORTON, Secretary
}

\author{
U.S. GEOLOGICAL SURVEY \\ Charles G. Groat, Director
}

The use of firm, trade, and brand names in this report is for identification purposes only and does not constitute endorsement by the U.S. Geological Survey.

For additional information write to:

District Chief

U.S. Geological Survey

Box 25046, Mail Stop 415

Denver Federal Center

Denver, CO 80225-0046
Copies of this report can be purchased from:
U.S. Geological Survey
Information Services
Box 25286
Denver Federal Center
Denver, CO 80225 


\section{CONTENTS}

Abstract...

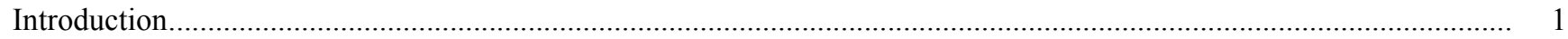

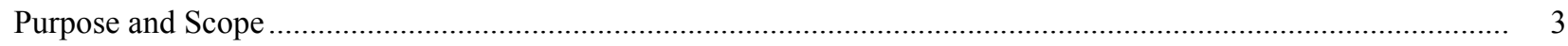

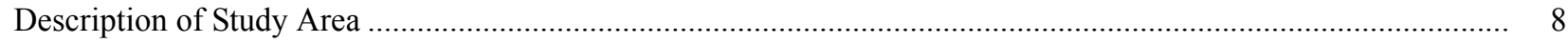

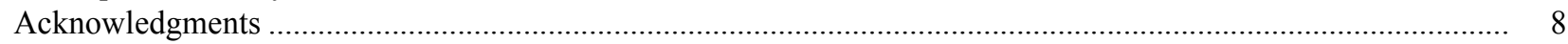

Organization of Discharge and Streamflow Characteristics Data on the CD-ROM …................................................. 8

Description of Streamflow Characteristics Data on the CD-ROM ........................................................................... 9

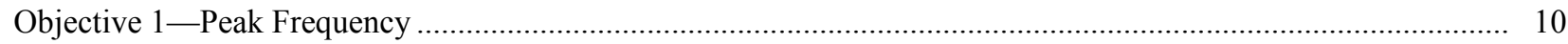

Objective 2 - Duration of Daily Mean Discharges on an Annual and Monthly Basis.......................................... 12

Duration of Annual and Monthly Mean Discharges........................................................................... 16

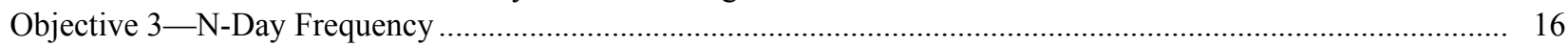

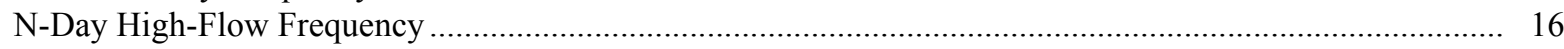

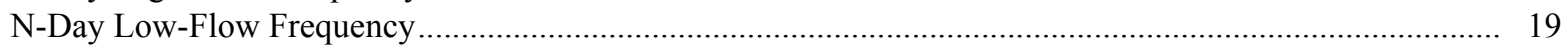

Objective 4-Mean and Median Discharge on an Annual and Monthly Basis................................................... 29

Frequency of Annual and Monthly Mean and Median Discharges ................................................................ 29

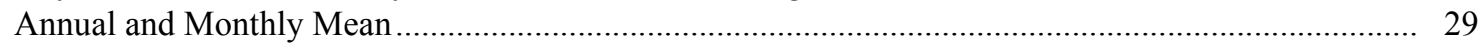

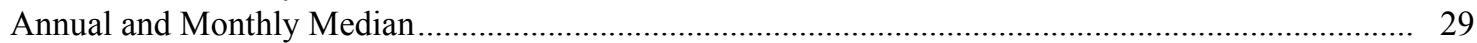

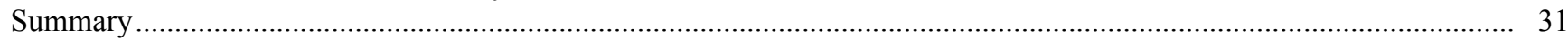

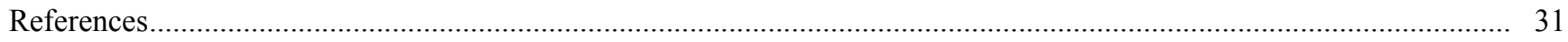

\section{FIGURES}

1. Map showing selected streamflow-gaging stations in the Grand Mesa, Uncompahgre, and Gunnison

National Forests study area .

2-10. Example graphs for results of:

2. Peak frequency computation .

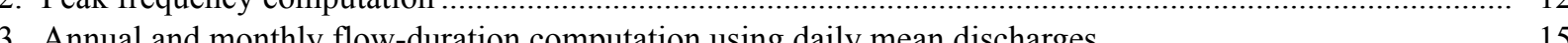

4. Monthly flow-duration computation during winter using daily mean discharges ........................... 15

5. Annual flow-duration computation using annual mean discharges ............................................................ 19

6. Monthly flow-duration computation using monthly mean discharges...................................................... 20

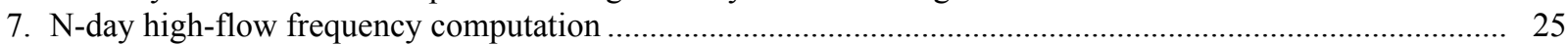

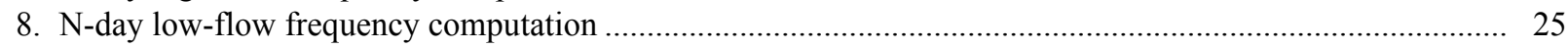

9. Frequency computation using annual and monthly mean discharges ...................................................... 28

10. Frequency computation using annual and monthly median discharges .................................................... 30

\section{TABLES}

1. Selected streamflow-gaging stations in and adjacent to the Grand Mesa, Uncompahgre, and Gunnison National Forests

2. Periods of daily mean discharge record for stations in and adjacent to the Grand Mesa, Uncompahgre, and Gunnison National Forests

3-14. Example data tables for:

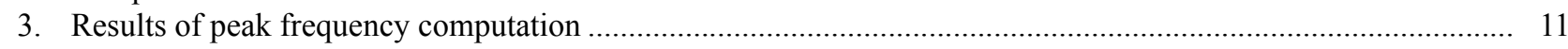

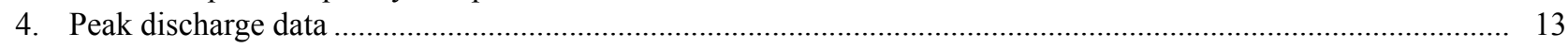

5. Results of annual and monthly flow-duration computation using daily mean discharges ................................... 14

6. Results of annual and monthly flow-duration computation using annual and monthly mean

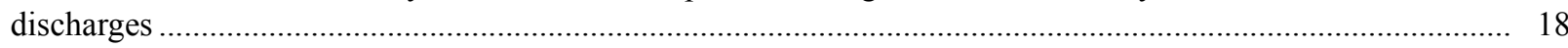

7. Annual values of $\mathrm{N}$-day high flow used in log-Pearson type-III frequency computation ................................... 21

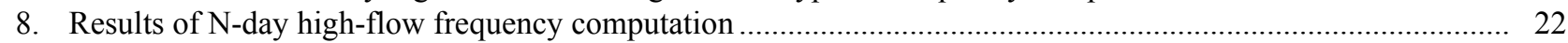

9. Annual values of N-day low flow used in log-Pearson type-III frequency computation.................................... 23

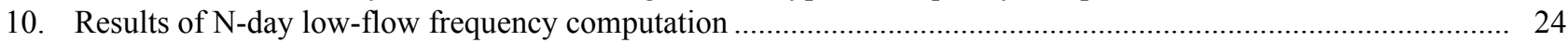

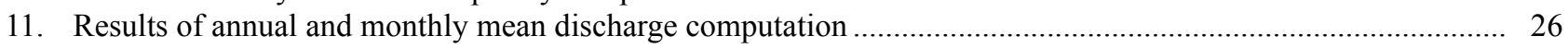

12. Results of annual and monthly median discharge computation .................................................................... 27 
13. Results of frequency computation using annual and monthly mean discharges............................................. 28

14. Results of frequency computation using annual and monthly median discharges........................................... 30

\section{CONVERSION FACTORS}

\begin{tabular}{rcl}
\hline \multicolumn{1}{c}{ Multiply } & \multicolumn{1}{c}{ By } & \multicolumn{1}{c}{ To obtain } \\
acre-foot $(\mathrm{acre}-\mathrm{ft})$ & 1,233 & square hectometer \\
cubic foot per second $\left(\mathrm{ft}^{3} / \mathrm{s}\right)$ & 0.4047 & cubic meter \\
foot $(\mathrm{ft})$ & 0.3048 & cubic meter per second \\
inch & 25.4 & meter \\
mile $\left(\mathrm{mi}^{2}\right)$ & 1.609 & millimeter \\
square mile $\left(\mathrm{mi}^{2}\right)$ & 2.590 & kilometer \\
\hline
\end{tabular}

Degree Celsius $\left({ }^{\circ} \mathrm{C}\right)$ may be converted to degree Fahrenheit $\left({ }^{\circ} \mathrm{F}\right)$ by using the following equation:

${ }^{\circ} \mathrm{F}=9 / 5\left({ }^{\circ} \mathrm{C}\right)+32$ 


\title{
Streamflow Characteristics for Selected Stations In and Near the Grand Mesa, Uncompahgre, and Gunnison National Forests, Southwestern Colorado
}

\author{
By Gerhard Kuhn
}

\section{Abstract}

The U.S Geological Survey, in cooperation with the Grand Mesa, Uncompahgre, and Gunnison National Forests, began a study in 2000 to develop selected streamflow characteristics for 60 streamflow-gaging stations in and near the Grand Mesa, Uncompahgre, and Gunnison National Forests. The study area is located in southwestern Colorado within the Gunnison River, Dolores River, and Plateau Creek Basins, which are tributaries of the Colorado River.

In addition to presenting the compiled daily, monthly, and annual discharge data for the 60 stations, the report presents tabular and graphical results for the following computed streamflow characteristics: (1) Instantaneous peak-flow frequency; (2) flow duration for daily mean discharges on an annual (water year) basis and on a monthly basis, and flow duration for the annual and monthly mean discharges; (3) low-flow and high-flow frequency of daily mean discharges for periods of $1,3,7,15,30,60,120$, and 183 consecutive days; and (4) annual and monthly mean and median discharges for each year and month of record, and frequency of the annual and monthly mean and median discharges. All discharge data and results from the streamflow-characteristics analyses are presented in Microsoft Excel workbooks on the enclosed CD-ROM.

\section{INTRODUCTION}

The U.S. Department of Agriculture, Forest Service, manages more than 191 million acres of
Federal land in 44 States, Puerto Rico, and the Virgin Islands; these lands possess resources and values of major economic, social, and environmental importance to the Nation. National Forests and Grasslands each have a Land and Resources Management Plan (LRMP) that is prepared in compliance with the National Forest Management Act of 1976 (U.S. Department of Agriculture, 2002c) and the National Environmental Policy Act of 1969 (U.S. Environmental Protection Agency, 2002). LRMPs typically need to be revised every 15 years (U.S. Department of Agriculture, 2002a, 2002b).

The LRMP for the Grand Mesa, Uncompahgre, and Gunnison National Forests in southwestern Colorado (fig. 1) was completed in 1983 and was revised substantially in 1991. Since completion of the 1983 LRMP, the areas in and adjacent to the Grand Mesa, Uncompahgre, and Gunnison National Forests (hereinafter, study area) have experienced increases in population and development of private land, increases in recreational use, and changes in the demand and use of natural resources. Additionally, there have been advances in scientific understanding of forest ecosystems (Robert L. Storch, U.S. Department of Agriculture, written commun., 2001). Because the LRMP has not been revised for a number of years and because of the changes in resource knowledge and use, the Grand Mesa, Uncompahgre, and Gunnison National Forests are in the process of revising their LRMP (Federal Register, 1999).

A number of water-resources issues have been identified in revising the LRMP for the study area. These issues include the following: (1) How do various activities in the forests affect water quality and quantity, soil resources, and riparian areas? (2) How can a revised management plan further the implementation of the National Clean Water Action Plan and 
Grand Mesa, Gunnison National Forest

28 U.S. Geological Surve streamflow-gaging station and map
number (table 1 )

$$
109^{\circ}
$$
$108^{\circ}$

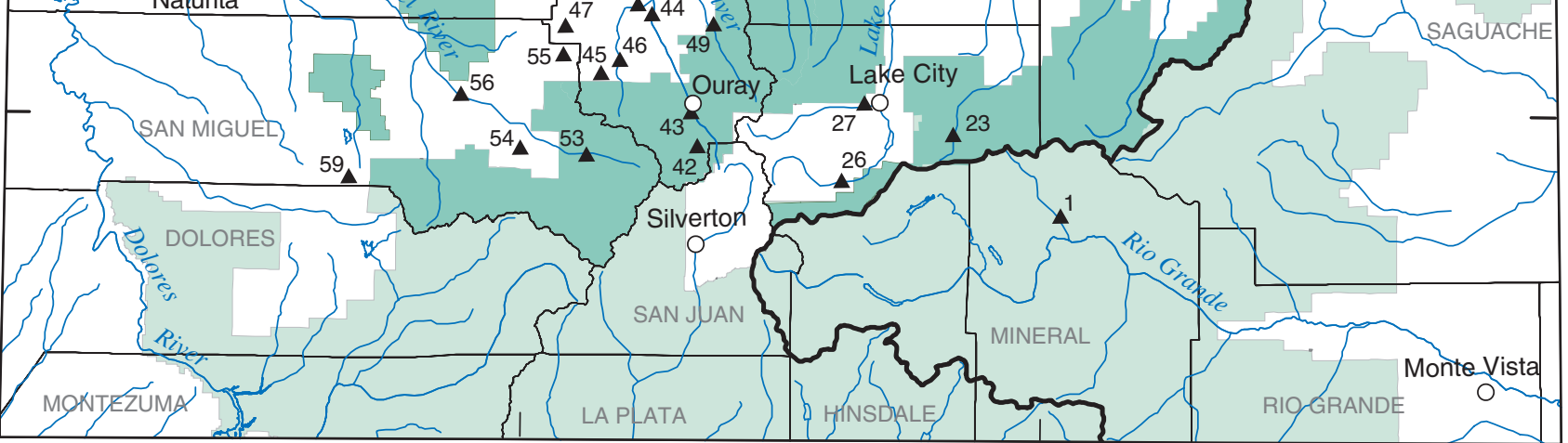

Base from U. S. Geological Survey, U.S. Census Bureau
and U.S. Fish and Willifife Service digital data, 1980-99

Standard parallels $20^{\circ} 30^{\circ} \mathrm{N}$ ans ${ }^{\circ} 49^{\circ} 30^{\circ} \mathrm{N}$, central meridian $104^{\circ} \mathrm{W}$

20 MILES

Latitude of projection origin $23^{\circ} \mathrm{N}$

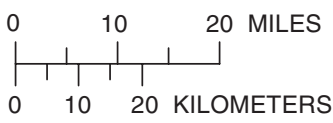

Figure 1. Selected streamflow-gaging stations in the Grand Mesa, Uncompahgre, and Gunnison National Forests study area. 
Policy and the framework for developing and implementing Total Maximum Daily Loads (TMDLs) in forest and rangeland environments? (3) In which stream or lake systems is improved programmatic direction needed to ensure the viability of aquatic species or to restore dwindling populations? (4) How should surface-water uses, including types and levels of use on lakes and streams, be regulated to maintain quality of the recreation experiences and protect natural resources? (Federal Register, 1999).

To evaluate these and other water-related issues and to formulate management actions that result in the best management of water and water-related resources, managers for the Grand Mesa, Uncompahgre, and Gunnison National Forests have identified a need for (1) scientifically based streamflow data to support instream flow analysis that is acceptable to all interested parties and (2) an analysis of streamflow data in order to describe and understand the seasonal and annual variability. To provide the needed streamflow data and analysis, the U.S Geological Survey (USGS), in cooperation with the Grand Mesa, Uncompahgre, and Gunnison National Forests, began a study in 2000 to develop selected streamflow characteristics using historical discharge data for 60 streamflow-gaging stations (hereinafter, stations) in and near the study area. The study would result in an update for some streamflow characteristics previously compiled for some of the stations (Richter and others, 1984).

\section{Purpose and Scope}

The purpose of this report is to present streamflow characteristics for 60 stations (fig. 1, table 1) in tabular and graphical form. Specifically, this report presents the compiled daily, monthly, and annual mean discharge data for the 60 stations from the beginning of available daily discharge data through water year 2000 (table 2) and results for the following computed streamflow characteristics:

\section{Instantaneous peak-flow frequency computed for} 43 stations that had 10 or more complete years of record (table 2) using the log-Pearson type III (LP3) distribution. The results include the annual instantaneous peak discharges that have a 1.5and 2.33-year recurrence interval along with the corresponding stages (gage heights) taken from the most recent or last rating curve in use. Stations 09145000 and 09174500 have less than 10 complete years of record (table 2) but were included in this analysis because, for station 09145000, peak discharge data were available for a few additional years other than the period of daily discharge record and, for station 09174500 , the peak discharge for water year 1942 (partial record) was available, providing 10 instantaneous peaks; therefore, peak-flow frequency was computed for a total of 45 stations.

2. Flow duration computed for daily mean discharges on (a) an annual (water year) basis and (b) a monthly basis; these analyses were made for all 60 stations. Additional results include flow duration computed for annual and monthly mean discharges; these analyses were made for 28 stations with 18 or more years of record (table 2).

3. N-day low-flow and high-flow frequency computed for daily mean discharges using the LP3 distribution; these analyses were made for $1,3,7,15$, $30,60,120$, and 183 consecutive days and for 43 stations that had 10 or more complete years of record (table 2).

4. Annual and monthly mean and median discharges for each year and month of record computed from the daily mean discharge data; these analyses were performed for all 60 stations (table 1). Additional analysis included frequency of the annual and monthly mean and median annual discharges computed for 43 stations that had 10 or more complete years of record (table 2) using the LP3 distribution. Because station 09174500 has 10 years of record for some months (table 2), frequency of the monthly mean and median discharges also were computed for those months.

The cooperative study with the Grand Mesa, Uncompahgre, and Gunnison National Forests required that results of the streamflow characteristics analyses be provided in digital (computerized) format; hence, all discharge data and results from the four study objectives are presented in Microsoft Excel workbooks (hereinafter, Excel files) on the enclosed CD-ROM. A brief description of the organization and content of the digital data are described in the subsequent sections of this report. 
Table 1. Selected streamflow-gaging stations in and adjacent to the Grand Mesa, Uncompahgre, and Gunnison National Forests

$[--$, no data $]$

\begin{tabular}{|c|c|c|c|c|c|c|c|}
\hline $\begin{array}{c}\text { Map } \\
\text { number } \\
\text { (figure 1) }\end{array}$ & $\begin{array}{l}\text { Station } \\
\text { number }\end{array}$ & Station name ${ }^{1}$ & $\begin{array}{l}\text { Latitude } \\
\text { (degrees, } \\
\text { minutes, } \\
\text { seconds) }\end{array}$ & $\begin{array}{l}\text { Longitude } \\
\text { (degrees, } \\
\text { minutes, } \\
\text { seconds) }\end{array}$ & $\begin{array}{l}\text { Drainage } \\
\text { area } \\
\text { (square } \\
\text { miles) }\end{array}$ & $\begin{array}{c}\text { Station } \\
\text { elevation } \\
\text { (feet) }\end{array}$ & $\begin{array}{c}\text { Annual } \\
\text { mean } \\
\text { discharge } \\
\text { (cubic feet } \\
\text { per }\end{array}$ \\
\hline 1 & 08216500 & Willow Creek at Creede & 375122 & 1065537 & 35.3 & 8,880 & 21.8 \\
\hline 2 & 08224500 & $\begin{array}{l}\text { Kerber Creek at Ashley Ranch near Villa } \\
\text { Grove }\end{array}$ & $38 \quad 14 \quad 28$ & 1060657 & 38.0 & 8,830 & 12.4 \\
\hline 3 & 09092500 & Beaver Creek near Rifle & $\begin{array}{lll}39 & 28 & 19\end{array}$ & 1074955 & 7.90 & 6,685 & 4.65 \\
\hline 4 & 09095800 & Plateau Creek near Heiberger & $\begin{array}{lll}39 & 13 & 03\end{array}$ & 1074626 & 18.6 & 8,016 & 9.12 \\
\hline 5 & 09096800 & $\begin{array}{l}\text { Buzzard Creek below Owens Creek near } \\
\text { Heiberger }\end{array}$ & $39 \quad 14 \quad 10$ & 1073800 & 49.7 & 8,206 & 25.2 \\
\hline 6 & 09097500 & Buzzard Creek near Collbran & $39 \quad 19 \quad 30$ & $107 \quad 50 \quad 29$ & 143 & 6,955 & 46.6 \\
\hline 7 & 09097600 & Brush Creek near Collbran & $\begin{array}{lll}39 & 19 & 30\end{array}$ & $107 \quad 50 \quad 30$ & 9.57 & 8,183 & 6.78 \\
\hline 8 & 09099500 & Big Creek at upper station near Collbran & 390755 & 1075505 & 20.2 & 8,590 & 27.0 \\
\hline 9 & 09104500 & Mesa Creek near Mesa & $3905 \quad 11$ & $108 \quad 07 \quad 34$ & 6.79 & 7,400 & 11.8 \\
\hline 10 & 09107000 & Taylor River at Taylor Park & $3851 \quad 37$ & 1063358 & 128 & 9,340 & 109 \\
\hline 11 & 09107500 & Texas Creek at Taylor Park & $3850 \quad 41$ & 1063412 & 40.4 & 9,300 & 35.5 \\
\hline 12 & 09108000 & Willow Creek at Taylor Park & $38 \quad 48 \quad 58$ & 1063144 & 47.0 & 9,490 & 24.9 \\
\hline 13 & 09110500 & East River near Crested Butte & 385152 & 1065433 & 90.3 & 8,880 & 139 \\
\hline 14 & 09111500 & Slate River near Crested Butte & $38 \quad 52 \quad 11$ & 1065808 & 68.9 & 8,820 & 143 \\
\hline 15 & 09112000 & Cement Creek near Crested Butte & 384928 & 1065108 & 26.1 & 9,050 & 36.5 \\
\hline 16 & 09112200 & $\begin{array}{l}\text { East River below Cement Creek near Crested } \\
\text { Butte }\end{array}$ & $\begin{array}{lll}38 & 47 & 03\end{array}$ & 1065213 & 238 & 8,440 & 336 \\
\hline 17 & 09112500 & East River at Almont & $38 \quad 3952$ & 1065051 & 289 & 8,006 & 340 \\
\hline 18 & 09113300 & Ohio Creek at Baldwin & $38 \quad 45 \quad 56$ & $107 \quad 03 \quad 28$ & 47.2 & 8,600 & 47.6 \\
\hline 19 & 09115500 & Tomichi Creek at Sargents & $38 \quad 24 \quad 42$ & 1062520 & 149 & 8,416 & 63.6 \\
\hline 20 & 09118000 & Quartz Creek near Ohio City & $3833 \quad 35$ & 1063809 & 106 & 8,430 & 54.3 \\
\hline 21 & 09118450 & $\begin{array}{l}\text { Cochetopa Creek below Rock Creek near } \\
\text { Parlin }\end{array}$ & 382008 & 1064618 & 334 & 8,475 & 47.3 \\
\hline 22 & 09119000 & Tomichi Creek at Gunnison & $38 \quad 31 \quad 18$ & 1065625 & 1,061 & 7,629 & 175 \\
\hline 23 & 09121500 & Cebolla Creek near Lake City & 375852 & $107 \quad 1005$ & 25.2 & 10,200 & 14.4 \\
\hline 24 & 09122000 & Cebolla Creek at Powderhorn & $38 \quad 1729$ & 1070650 & 340 & 8,000 & 102 \\
\hline 25 & 09122500 & Soap Creek near Sapinero & 383339 & $107 \quad 1858$ & 57.4 & 7,790 & 58.6 \\
\hline 26 & 09123400 & Lake Fork below Mill Gulch near Lake City & 375423 & 1072303 & 57.5 & 9,400 & 101 \\
\hline 27 & 09124000 & Henson Creek at Lake City & $\begin{array}{lll}38 & 01 & 11\end{array}$ & 1072005 & 83.1 & 8,750 & 100 \\
\hline 28 & 09124500 & Lake Fork at Gateview & $38 \quad 17 \quad 56$ & $107 \quad 1346$ & 334 & 7,828 & 238 \\
\hline 29 & 09125000 & Curecanti Creek near Sapinero & 382916 & 1072452 & 35.0 & 7,867 & 32.3 \\
\hline 30 & 09127500 & Crystal Creek near Maher & $\begin{array}{lll}38 & 33 & 07\end{array}$ & 1073020 & 42.2 & 8,070 & 28.2 \\
\hline
\end{tabular}


Table 1. Selected streamflow-gaging stations in and adjacent to the Grand Mesa, Uncompahgre, and Gunnison National Forests-Continued

$[--$, no data $]$

\begin{tabular}{|c|c|c|c|c|c|c|c|}
\hline $\begin{array}{c}\text { Map } \\
\text { number } \\
\text { (figure 1) }\end{array}$ & $\begin{array}{l}\text { Station } \\
\text { number }\end{array}$ & Station name ${ }^{1}$ & $\begin{array}{l}\text { Latitude } \\
\text { (degrees, } \\
\text { minutes, } \\
\text { seconds) }\end{array}$ & $\begin{array}{l}\text { Longitude } \\
\text { (degrees, } \\
\text { minutes, } \\
\text { seconds) }\end{array}$ & $\begin{array}{l}\text { Drainage } \\
\text { area } \\
\text { (square } \\
\text { miles) }\end{array}$ & $\begin{array}{c}\text { Station } \\
\text { elevation } \\
\text { (feet) }\end{array}$ & $\begin{array}{c}\text { Annual } \\
\text { mean } \\
\text { discharge } \\
\text { (cubic feet } \\
\text { per } \\
\text { second) }\end{array}$ \\
\hline 31 & 09128500 & Smith Fork near Crawford & $3843 \quad 40$ & 1073022 & 42.8 & 7,091 & 42.8 \\
\hline 32 & 09129800 & Clear Fork near Ragged Mountain & $3908 \quad 36$ & $10725 \quad 50$ & 38.5 & 7,450 & 36.8 \\
\hline 33 & 09130500 & East Muddy Creek near Bardine & $3900 \quad 48$ & 1072128 & 133 & 6,655 & 88.4 \\
\hline 34 & 09130600 & West Muddy Creek near Ragged Mountain & $3907 \quad 51$ & 1073429 & 7.42 & 8,658 & 4.76 \\
\hline 35 & 09131200 & West Muddy Creek near Somerset & $\begin{array}{lll}39 & 05 & 23\end{array}$ & 1073017 & 49.9 & 8,020 & 31.6 \\
\hline 36 & 09132000 & Ruby Anthracite Creek near Floresta & $3851 \quad 47$ & $107 \quad 0948$ & 20.7 & 8,805 & 43.9 \\
\hline 37 & 09132900 & West Hubbard Creek near Paonia & 390156 & 1073647 & 2.34 & 9,640 & 3.54 \\
\hline 38 & 09134000 & Minnesota Creek near Paonia & $\begin{array}{lll}38 & 52 & 13\end{array}$ & 1073006 & 41.5 & 6,200 & 23.4 \\
\hline 39 & 09134500 & Leroux Creek near Cedaredge & $38 \quad 55 \quad 35$ & $10747 \quad 35$ & 34.5 & 7,255 & 47.6 \\
\hline 40 & 09134700 & Cow Creek near Cedaredge & 385534 & 1074731 & 7.24 & 7,268 & 13.2 \\
\hline 41 & 09143000 & Surface Creek near Cedaredge & 385905 & $10751 \quad 13$ & 27.4 & 8,261 & 43.2 \\
\hline 42 & 09144500 & Red Mountain Creek near Ironton & 375746 & 1073944 & 18.1 & 9,586 & 30.9 \\
\hline 43 & 09145000 & Uncompahgre River at Ouray & $\begin{array}{lll}38 & 01 & 09\end{array}$ & $107 \quad 40 \quad 32$ & 42.0 & 7,800 & 90.5 \\
\hline 44 & 09146200 & Uncompahgre River near Ridgway & $\begin{array}{lll}38 & 11 & 02\end{array}$ & $10744 \quad 43$ & 149 & 6,878 & 167 \\
\hline 45 & 09146400 & West Fork Dallas Creek near Ridgway & $3804 \quad 25$ & $10751 \quad 02$ & 14.1 & 8,400 & 12.8 \\
\hline 46 & 09146500 & East Fork Dallas Creek near Ridgway & $\begin{array}{lll}38 & 05 & 36\end{array}$ & $10748 \quad 47$ & 16.8 & 7,980 & 25.2 \\
\hline 47 & 09146600 & Pleasant Valley Creek near Noel & $38 \quad 08 \quad 44$ & 1075509 & 8.17 & 8,680 & 2.22 \\
\hline 48 & 09147000 & Dallas Creek near Ridgway & $38 \quad 10 \quad 40$ & 1074528 & 97.2 & 6,980 & 40.1 \\
\hline 49 & 09147100 & Cow Creek near Ridgway & $38 \quad 0858$ & 1073839 & 45.4 & 7,620 & 61.0 \\
\hline 50 & 09151500 & Escalante Creek near Delta & $38 \quad 45 \quad 24$ & $108 \quad 15 \quad 34$ & 209 & 4,810 & 60.4 \\
\hline 51 & 09152000 & Kannah Creek near Whitewater & $38 \quad 57 \quad 42$ & $108 \quad 13 \quad 47$ & 61.9 & 6,060 & 30.9 \\
\hline 52 & 09163570 & $\begin{array}{l}\text { Hay Press Creek above Fruita Reservoir } \\
\text { No. } 3 \text { near Glade Park }\end{array}$ & $3851 \quad 03$ & 1084656 & .77 & 8,990 & 0.71 \\
\hline 53 & 09171200 & San Miguel River near Telluride & 375653 & 1075235 & 42.8 & 8,622 & 63.3 \\
\hline 54 & 09172000 & Fall Creek near Fall Creek & $3757 \quad 30$ & $108 \quad 0019$ & 33.4 & 7,929 & 24.6 \\
\hline 55 & 09172100 & Leopard Creek at Noel & 380606 & 1075522 & 9.03 & 8,700 & 2.74 \\
\hline 56 & 09172500 & San Miguel River near Placerville & $\begin{array}{lll}38 & 02 & 05\end{array}$ & $108 \quad 07 \quad 15$ & 308 & 7,056 & 240 \\
\hline 57 & 09173500 & Horsefly Creek near Sams & $\begin{array}{lll}38 & 12 & 14\end{array}$ & $108 \quad 03 \quad 25$ & 28.8 & 8,330 & 9.19 \\
\hline 58 & 09174500 & Cottonwood Creek near Nucla & $38 \quad 16 \quad 25$ & 1082144 & 38.8 & 6,080 & 4.75 \\
\hline 59 & 09174700 & $\begin{array}{l}\text { West Naturita Creek at upper station } \\
\text { near Norwood }\end{array}$ & 375439 & 1082008 & 7.31 & 8,180 & -- \\
\hline 60 & 09176500 & Tabeguache Creek near Nucla & $38 \quad 2208$ & $108 \quad 20 \quad 42$ & 16.9 & 8,010 & 11.2 \\
\hline
\end{tabular}


Table 2. Periods of daily mean discharge record for stations in and adjacent to the Grand Mesa, Uncompahgre, and Gunnison National Forests

$[--$, not computed]

\begin{tabular}{|c|c|c|c|c|}
\hline $\begin{array}{c}\text { Map } \\
\text { number } \\
\text { (figure 1) }\end{array}$ & $\begin{array}{l}\text { Station } \\
\text { number } \\
\text { (table 1) }\end{array}$ & $\begin{array}{l}\text { Time periods for which daily } \\
\text { discharge data are available }\end{array}$ & $\begin{array}{l}\text { Number of } \\
\text { complete water } \\
\text { years in each } \\
\text { time period }\end{array}$ & $\begin{array}{l}\text { Total number } \\
\text { of complete } \\
\text { water years }\end{array}$ \\
\hline 1 & 08216500 & $06 / 01 / 1951$ to $09 / 30 / 1982$ & 31 & 31 \\
\hline 2 & 08224500 & $\begin{array}{l}06 / 01 / 1923 \text { to } 09 / 30 / 1926 \\
05 / 01 / 1936 \text { to } 09 / 30 / 1982 \\
10 / 01 / 1998 \text { to } 09 / 30 / 2000\end{array}$ & $\begin{array}{r}3 \\
46 \\
2\end{array}$ & $\begin{array}{l}-- \\
-- \\
51\end{array}$ \\
\hline 3 & 09092500 & $10 / 01 / 1952$ to $09 / 30 / 1982$ & 30 & 30 \\
\hline 4 & 09095800 & $05 / 01 / 1958$ to $09 / 30 / 1964$ & 6 & 6 \\
\hline 5 & 09096800 & $10 / 01 / 1955$ to $09 / 30 / 1970$ & 15 & 15 \\
\hline 6 & 09097500 & $10 / 01 / 1921$ to $09 / 30 / 1980$ & 59 & 59 \\
\hline 7 & 09097600 & $10 / 01 / 1955$ to $09 / 30 / 1967$ & 12 & 12 \\
\hline 8 & 09099500 & $10 / 01 / 1945$ to $09 / 30 / 1956$ & 11 & 11 \\
\hline 9 & 09104500 & $10 / 01 / 1940$ to $09 / 30 / 1960$ & 20 & 20 \\
\hline 10 & 09107000 & $\begin{array}{l}06 / 01 / 1929 \text { to } 09 / 30 / 1934 \\
10 / 01 / 1987 \text { to } 09 / 30 / 2000\end{array}$ & $\begin{array}{r}5 \\
13\end{array}$ & $\overline{18}$ \\
\hline 11 & 09107500 & $\begin{array}{l}06 / 01 / 1929 \text { to } 09 / 30 / 1934 \\
10 / 01 / 1987 \text { to } 09 / 30 / 1992\end{array}$ & $\begin{array}{l}5 \\
5\end{array}$ & $\overline{--}$ \\
\hline 12 & 09108000 & $06 / 01 / 1929$ to $09 / 30 / 1934$ & 5 & 5 \\
\hline 13 & 09110500 & $11 / 01 / 1939$ to $09 / 30 / 1951$ & 11 & 11 \\
\hline 14 & 09111500 & $\begin{array}{l}04 / 01 / 1940 \text { to } 09 / 30 / 1951 \\
10 / 01 / 1993 \text { to } 09 / 30 / 2000\end{array}$ & $\begin{array}{r}11 \\
7\end{array}$ & $\overline{18}$ \\
\hline 15 & 09112000 & $\begin{array}{l}10 / 01 / 1910 \text { to } 12 / 31 / 1913 \\
04 / 01 / 1940 \text { to } 09 / 30 / 1951\end{array}$ & $\begin{array}{r}3 \\
11\end{array}$ & $\overline{14}$ \\
\hline 16 & 09112200 & $\begin{array}{l}10 / 01 / 1963 \text { to } 09 / 30 / 1972 \\
10 / 01 / 1979 \text { to } 09 / 30 / 1981 \\
10 / 01 / 1993 \text { to } 09 / 30 / 2000\end{array}$ & $\begin{array}{l}9 \\
2 \\
7\end{array}$ & $\begin{array}{c}-- \\
-- \\
18\end{array}$ \\
\hline 17 & 09112500 & $\begin{array}{l}10 / 01 / 1910 \text { to } 09 / 30 / 1922 \\
10 / 01 / 1934 \text { to } 09 / 30 / 2000\end{array}$ & $\begin{array}{l}12 \\
66\end{array}$ & -- \\
\hline 18 & 09113300 & $10 / 01 / 1958$ to $09 / 30 / 1970$ & 12 & 12 \\
\hline 19 & 09115500 & $\begin{array}{l}10 / 01 / 1916 \text { to } 09 / 30 / 1922 \\
10 / 01 / 1937 \text { to } 09 / 30 / 1972 \\
10 / 01 / 1992 \text { to } 09 / 30 / 2000\end{array}$ & $\begin{array}{r}6 \\
35 \\
8\end{array}$ & $\begin{array}{c}-- \\
-- \\
49\end{array}$ \\
\hline 20 & 09118000 & $\begin{array}{l}10 / 01 / 1937 \text { to } 09 / 30 / 1950 \\
10 / 01 / 1959 \text { to } 09 / 30 / 1970\end{array}$ & $\begin{array}{l}13 \\
11\end{array}$ & 24 \\
\hline 21 & 09118450 & $10 / 01 / 1981$ to $09 / 30 / 2000$ & 19 & 19 \\
\hline 22 & 09119000 & $10 / 01 / 1937$ to $09 / 30 / 2000$ & 63 & 63 \\
\hline 23 & 09121500 & $08 / 01 / 1946$ to $09 / 30 / 1954$ & 8 & 8 \\
\hline 24 & 09122000 & $10 / 01 / 1937$ to $09 / 30 / 1955$ & 18 & 18 \\
\hline 25 & 09122500 & $08 / 01 / 1955$ to $09 / 30 / 1966$ & 11 & 11 \\
\hline 26 & 09123400 & $10 / 01 / 1981$ to $09 / 30 / 1986$ & 5 & 5 \\
\hline 27 & 09124000 & $\begin{array}{l}10 / 01 / 1917 \text { to } 09 / 30 / 1919 \\
10 / 01 / 1931 \text { to } 09 / 30 / 1937\end{array}$ & $\begin{array}{l}2 \\
6\end{array}$ & $\overline{--}$ \\
\hline 28 & 09124500 & $10 / 01 / 1937$ to $09 / 30 / 2000$ & 63 & 63 \\
\hline 29 & 09125000 & $10 / 01 / 1945$ to $09 / 30 / 1972$ & 27 & 27 \\
\hline 30 & 09127500 & $\begin{array}{l}10 / 01 / 1945 \text { to } 09 / 30 / 1954 \\
10 / 01 / 1960 \text { to } 09 / 30 / 1969\end{array}$ & $\begin{array}{l}9 \\
9\end{array}$ & $\overline{18}$ \\
\hline 31 & 09128500 & $10 / 01 / 1935$ to $09 / 30 / 1994$ & 59 & 59 \\
\hline
\end{tabular}


Table 2. Periods of daily mean discharge record for stations in and adjacent to the Grand Mesa, Uncompahgre, and Gunnison National Forests-Continued

$[--$, not computed]

\begin{tabular}{|c|c|c|c|c|}
\hline $\begin{array}{c}\text { Map } \\
\text { number } \\
\text { (figure 1) }\end{array}$ & $\begin{array}{l}\text { Station } \\
\text { number } \\
\text { (table 1) }\end{array}$ & $\begin{array}{l}\text { Time periods for which daily } \\
\text { discharge data are available }\end{array}$ & $\begin{array}{l}\text { Number of } \\
\text { complete water } \\
\text { years in each } \\
\text { time period }\end{array}$ & $\begin{array}{l}\text { Total number } \\
\text { of complete } \\
\text { water years }\end{array}$ \\
\hline 32 & 09129800 & $10 / 01 / 1965$ to $09 / 30 / 1973$ & 8 & 8 \\
\hline 33 & 09130500 & $10 / 01 / 1934$ to $09 / 30 / 1953$ & 19 & 19 \\
\hline 34 & 09130600 & $10 / 01 / 1955$ to $09 / 30 / 1965$ & 10 & 10 \\
\hline 35 & 09131200 & $10 / 01 / 1961$ to $09 / 30 / 1973$ & 12 & 12 \\
\hline 36 & 09132000 & $\begin{array}{l}10 / 01 / 1938 \text { to } 09 / 30 / 1943 \\
10 / 01 / 1954 \text { to } 09 / 30 / 1958\end{array}$ & $\begin{array}{l}5 \\
4\end{array}$ & $\begin{array}{l}-- \\
9\end{array}$ \\
\hline 37 & 09132900 & $10 / 01 / 1960$ to $09 / 30 / 1973$ & 13 & 13 \\
\hline 38 & 09134000 & $\begin{array}{l}10 / 01 / 1936 \text { to } 09 / 30 / 1947 \\
10 / 01 / 1985 \text { to } 09 / 30 / 2000\end{array}$ & $\begin{array}{l}11 \\
15\end{array}$ & $\overline{26}$ \\
\hline 39 & 09134500 & $\begin{array}{l}10 / 01 / 1936 \text { to } 09 / 30 / 1956 \\
10 / 01 / 1960 \text { to } 09 / 30 / 1969\end{array}$ & $\begin{array}{r}20 \\
9\end{array}$ & -- \\
\hline 40 & 09134700 & $10 / 01 / 1960$ to $09 / 30 / 1969$ & 9 & 9 \\
\hline 41 & 09143000 & $\begin{array}{l}07 / 01 / 1939 \text { to } 10 / 31 / 1999 \\
04 / 01 / 2000 \text { to } 09 / 30 / 2000\end{array}$ & $\begin{array}{r}60 \\
0\end{array}$ & $\begin{array}{l}-- \\
60\end{array}$ \\
\hline 42 & 09144500 & $10 / 01 / 1947$ to $12 / 31 / 1955$ & 8 & 8 \\
\hline 43 & 09145000 & $04 / 01 / 1916$ to $09 / 30 / 1924$ & 8 & 8 \\
\hline 44 & 09146200 & $10 / 01 / 1958$ to $09 / 30 / 2000$ & 42 & 42 \\
\hline 45 & 09146400 & $10 / 01 / 1955$ to $09 / 30 / 1970$ & 15 & 15 \\
\hline 46 & 09146500 & $\begin{array}{l}10 / 01 / 1947 \text { to } 09 / 30 / 1953 \\
10 / 01 / 1960 \text { to } 09 / 30 / 1970\end{array}$ & $\begin{array}{r}6 \\
10\end{array}$ & -- \\
\hline 47 & 09146600 & $10 / 01 / 1955$ to $09 / 30 / 1967$ & 12 & 12 \\
\hline 48 & 09147000 & $\begin{array}{l}03 / 01 / 1922 \text { to } 09 / 30 / 1927 \\
10 / 01 / 1955 \text { to } 09 / 30 / 1971 \\
10 / 01 / 1979 \text { to } 09 / 30 / 2000\end{array}$ & $\begin{array}{r}5 \\
16 \\
21\end{array}$ & $\begin{array}{l}-- \\
-- \\
42\end{array}$ \\
\hline 49 & 09147100 & $10 / 01 / 1955$ to $09 / 30 / 1973$ & 18 & 18 \\
\hline 50 & 09151500 & $05 / 01 / 1976$ to $09 / 30 / 1989$ & 13 & 13 \\
\hline 51 & 09152000 & $\begin{array}{l}10 / 01 / 1917 \text { to } 09 / 30 / 1921 \\
09 / 01 / 1922 \text { to } 09 / 30 / 1982\end{array}$ & $\begin{array}{r}4 \\
60\end{array}$ & -- \\
\hline 52 & 09163570 & $10 / 01 / 1983$ to $03 / 31 / 1988$ & 4 & 4 \\
\hline 53 & 09171200 & $10 / 01 / 1959$ to $09 / 30 / 1965$ & 6 & 6 \\
\hline 54 & 09172000 & $08 / 01 / 1941$ to $09 / 30 / 1959$ & 18 & 18 \\
\hline 55 & 09172100 & $10 / 01 / 1955$ to $09 / 30 / 1963$ & 8 & 8 \\
\hline 56 & 09172500 & $\begin{array}{l}10 / 01 / 1910 \text { to } 09 / 30 / 1912 \\
10 / 01 / 1930 \text { to } 09 / 30 / 1934 \\
04 / 01 / 1942 \text { to } 09 / 30 / 2000\end{array}$ & $\begin{array}{r}2 \\
4 \\
58\end{array}$ & $\begin{array}{l}-- \\
-- \\
64\end{array}$ \\
\hline 57 & 09173500 & $10 / 01 / 1942$ to $09 / 30 / 1951$ & 9 & 9 \\
\hline 58 & 09174500 & $05 / 01 / 1942$ to $09 / 30 / 1951$ & 9 & 9 \\
\hline 59 & 09174700 & $\begin{array}{l}05 / 01 / 1975 \text { to } 07 / 31 / 1975 \\
04 / 01 / 1976 \text { to } 07 / 31 / 1976 \\
04 / 01 / 1977 \text { to } 07 / 31 / 1977 \\
04 / 01 / 1978 \text { to } 07 / 31 / 1978 \\
04 / 01 / 1979 \text { to } 07 / 31 / 1979 \\
04 / 01 / 1980 \text { to } 07 / 31 / 1980\end{array}$ & $\begin{array}{l}0 \\
0 \\
0 \\
0 \\
0 \\
0\end{array}$ & $\begin{array}{c}-- \\
-- \\
-- \\
-- \\
-- \\
0\end{array}$ \\
\hline 60 & 09176500 & $04 / 01 / 1946$ to $09 / 30 / 1953$ & 7 & 7 \\
\hline
\end{tabular}




\section{Description of Study Area}

The study area is located in southwestern Colorado (fig. 1) within the Gunnison River, Dolores River, and Plateau Creek Basins, which are tributaries of the Colorado River. The study area comprises about $12,890 \mathrm{mi}^{2}$ within the three drainage basins; however, the area within the Grand Mesa, Uncompahgre, and Gunnison National Forests is only about $4,940 \mathrm{mi}^{2}$ (about 3,161,600 acres). The study area has highly diverse physical, climatologic, and hydrologic characteristics.

The study area is in the Southern Rocky Mountains and Colorado Plateaus physiographic provinces (Fenneman, 1931), and elevations range from about $4,600 \mathrm{ft}$ at Grand Junction to about 14,000 ft at several mountain peaks near Lake City and Ouray. The large range in elevation and presence of numerous mountain ranges have a profound effect on precipitation, which ranges from about 8 inches per year at Grand Junction to about 40 inches per year in mountains along the Continental Divide (Colorado Climate Center, 1984). Differences in elevation also affect air temperature, which generally decreases about $5.4^{\circ} \mathrm{F}$ for every $1,000 \mathrm{ft}$ increase in elevation; annual mean temperature is about $54^{\circ} \mathrm{F}$ at Grand Junction and decreases to about $33^{\circ} \mathrm{F}$ at Taylor Park (near stations 10 and 11 in fig. 1) (Chaney and others, 1987, p. 12).

Because of the increase in precipitation and decrease in temperature associated with the increase in elevation, most precipitation during the months of October through May is in the form of snow, especially in the higher mountainous areas. The winter precipitation results in accumulation of mountain snowpacks with 10 to 25 inches of water equivalent; melting of the snowpack during April through July results in about 50 to 80 percent of the annual streamflow (Kuhn and Nickless, 1994, p. 5). Precipitation from rainfall during summer usually does not result in substantial streamflow, even though a summer monsoon often is prevalent in the area; however, lateseason rainfall from monsoonal precipitation during late September and early October in 1911 resulted in a record flood in parts of the Dolores River, San Juan River, and Rio Grande Basins (Clayton, 1912).

\section{Acknowledgments}

The author thanks John M. Almy and Warren Young, with the Grand Mesa, Uncompahgre, and Gunnison National Forests, for their assistance in providing the geographic information system (GIS) coverage of National Forest lands used in figure 1. Technical reviews of the report by Kirk A. Miller and Ryan F. Thompson, editorial review by Mary A. Kidd, preparation of the final manuscript by Alene $\mathrm{J}$. Brogan, and preparation of figure 1 by Jean A. Dupree, all USGS, are greatly appreciated.

\section{ORGANIZATION OF DISCHARGE AND STREAMFLOW CHARACTERISTICS DATA ON THE CD-ROM}

Data on the CD-ROM are arranged in a directory structure based on the four report purposes (study objectives) described in the "Purpose and Scope" section of this report. The following schematic illustrates the data structure (directories are in bold type and files are in italic type):

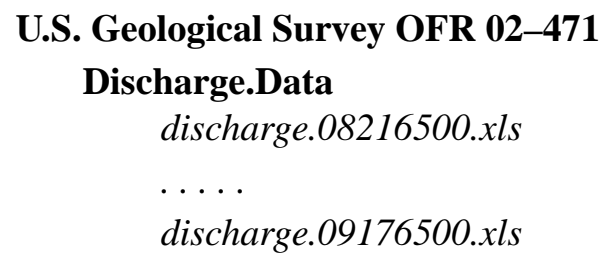

Objective.1 (Peak.Frequency) pkfq.08216500.xls

.....

pkfq.09174500.xls

Objective.2 (Annual-Monthly.Daily-Duration) flow-dur.08216500.xls

flow-dur.09176500.xls

Annual-Monthly.Mean.Flow-Duration ann-mon.dur.08216500.xls

ann-mon.dur.09172500.xls

Objective.3 (N-Day.Frequency)

$N$-Day-High.Frequency

nday-high.08216500.xls

.....

nday-high.09176500.xls 


$$
\begin{aligned}
& \text { N-Day-Low.Frequency } \\
& \text { nday-low.08216500.xls } \\
& \text {. . . } \\
& \text { nday-low.09176500.xls }
\end{aligned}
$$

Objective.4 (Annual-Monthly.Mean-Median)

mean_medn.08216500.xls

mean_medn.09176500.xls

Annual-Monthly.Mean-Frequency

ann-mon.mean-freq.08216500.xls

…

ann-mon.mean-freq.09174500.xls

Annual-Monthly.Median-Frequency

ann-mon.medn-freq.08216500.xls

.....

ann-mon.medn-freq.09174500.xls

\section{PDF.Hydrographs}

(Obj-1) Peak.Freq

pkfq.08216500.pdf

pkfq.09174500.pdf

(Obj-2) Ann-Mon.Daily.Duration

dly-dur.all.08216500.pdf

.....

dly-dur.all.09174500.pdf

(Obj-2) Ann-Mon.Mean.Dur

AM-mean-dur.all.08216500.pdf

$\ldots \ldots$

AM-mean-dur.all.09172500.pdf

(Obj-3) N-Day.High-Low.Freq

n-day.freq.08216500.pdf

$\ldots \ldots$

n-day.freq.09172500.pdf

(Obj-4) Ann-Mon.Mean.Freq

AM-mean-freq.all.08216500.pdf

AM-mean-freq.all.09174500.pdf

(Obj-4) Ann-Mon.Median.Freq

AM-medn-freq.all.08216500.pdf

$\ldots$

AM-medn-freq.all.09174500.pdf

ReadMe.txt

USGS_OFR.02-471.pdf

ar505enu.exe
All data are contained in the master directory "U.S. Geological Survey OFR 92-471" that contains subdirectories for (1) the daily, monthly, and annual discharge data; (2) each of the four streamflow characteristic objectives; and (3) Adobe portable document format for all the graphs of streamflow characteristics. In addition, the CD-ROM contains these additional files: (1) "ReadMe.txt" that provides an orientation to the contents of the CD-ROM; (2) "USGS OFR.02471.pdf" that contains the report text as a PDF file; and (3) "ar505.exe" that is the installation program for Adobe Acrobat Reader needed to view PDF files (for those users that do not have the program installed on their computer). In the directory schematic, only the first and last discharge data, streamflow characteristics data, and PDF files are listed - the line with the dots between the listed files (in italics) is intended to represent the many other files not listed in the schematic.

In the directories for each of the streamflow characteristics objectives, each Excel file (one file for each station for which a characteristic was computed) contains at least one worksheet with a data table listing the streamflow characteristic results and a graph showing the streamflow characteristic results; however, most Excel files have additional worksheets with additional data tables and graphs because multiple characteristics usually were computed. The computer programs used to derive the streamflow characteristics and graphs provided graphical output in the form of postscript files. The conversion filter used to import the postscript files into the Excel files resulted in a degraded image quality; therefore, PDF files, which have a higher image quality, are provided for each streamflow characteristic in the various subdirectories and files of the "PDF.Hydrographs" directory. A brief description of the streamflow characteristics data tables in the Excel files is presented in the next section of this report; no additional description of the PDF files is necessary.

\section{DESCRIPTION OF STREAMFLOW CHARACTERISTICS DATA ON THE CD-ROM}

A brief description of some data fields on the streamflow characteristics data tables in the Excel files is presented in the following report sections. The descriptions, however, are not intended to be an interpretation of the resulting output. No description of the daily, monthly, and annual discharges in the Excel files in the "Discharge.Data" directory is presented herein. 


\section{Objective 1—Peak Frequency}

Frequency analysis of instantaneous peak discharge was made using the USGS computer program PEAKFQ (U.S. Geological Survey, 2002a). This program uses the LP3 distribution for analysis and incorporates all of the additional computational procedures described in the report "Guidelines for Determining Flood Flow Frequency" that commonly, and hereinafter, is referred to as "Bulletin 17B" (U.S. Interagency Advisory Committee on Water Data, 1982).

An example of the Excel data table for results of peak frequency computation is shown in table 3 . The major components of the data table are as follows:

1. The station number and name.

2. A list of standard annual exceedance probabilities and recurrence intervals; the Bulletin 17B, systematic record, and "expected probability" estimated peak discharges for each listed exceedance probability and recurrence interval; and the 95-percent confidence limits for each Bulletin 17B peak discharge estimate. The Bulletin 17B estimated peak discharge estimates are the actual result of the analysis. The systematic record estimated peak discharges are included in the output from the PEAKFQ program for comparative purposes; the computations for the systematic record discharges are based on a simple LP3 frequency analysis without the computational enhancements described in Bulletin 17B (U.S. Interagency Advisory Committee on Water Data, 1982). The expected probability estimate discharge represents a measure of the central tendency of the spread between the confidence limits (U.S. Interagency Advisory Committee on Water Data, 1982, p. 24); additional discussion of expected probability estimate is presented in Appendix 11 of that publication (U.S. Interagency Advisory Committee on Water Data, 1982).

3. The estimated peak discharges for two additional annual exceedance probabilities and recurrence intervals, the 1.5-year and 2.33-year floods, together with the stage for the estimated discharges taken from the most recent or last discharge rating curve in use. Stage at a USGS gaging station is a measure of the stream surface elevation in reference to some arbitrary or predetermined datum (Rantz and others, 1982a, p. 23); therefore, stage may not necessarily be equivalent to the mean stream depth for a given discharge. (See Rantz and others [1982a, 1982b] for detailed discussion of stage measurement, rating curves, and computation of discharge.)

4. A summary of the input data that lists the number of peaks in the record, number of values not used in the analysis, and the generalized skew value.

5. The number of recorded peaks that were less than or greater than a listed high and low outlier criterion; the criteria are computed within the PEAKFQ program by using outlier computation techniques (U.S. Interagency Advisory Committee on Water Data, 1982, p. 17-18).

6. The computed parameters, in logarithmic units, for the LP3 distribution, for both the systematic record and for the Bulletin 17B methods.

7. A graph of the peak frequency analysis results is presented to the right of the Excel data table; an example is shown in figure 2 .

The peak discharges for each year of record are listed in a second worksheet of the Excel file; an example is shown in table 4. The listing of the recorded peak discharges includes a column for peak discharge codes; however, there were none for the example selected. An explanation of the peak discharges codes is included in table 4. In the Excel files, the explanation for the peak discharge codes is not provided in each Excel file but rather in a separate file, Peak_Q.Codes.xls, in the Objective.1

(Peak.Frequency) directory of the CD-ROM.

Station 09097600 Brush Creek near Collbran was selected for the example (fig. 2) because it illustrates frequency analysis results for shorter time periods that commonly do not have recorded peak discharges at the smaller exceedance probabilities (higher recurrence intervals). Hence, careful judgment needs to be used in interpreting and applying the frequency analysis results; the range of the 95-percent confidence limits, which is considerable for station 09097600 at the smaller exceedances, needs to be considered in any application of the Bulletin 17B estimated discharges. For stations with longer periods of record, the range of the recorded peak discharges usually will be larger (closer to the range of estimated peak discharges in the frequency table), and the range of the 95-percent confidence limits usually will be smaller.

The PEAKFQ program normally does not use discharge values that have a peak discharge code of 
Table 3. Example data table for results of peak frequency computation

\begin{tabular}{|c|c|c|c|c|c|c|}
\hline \multicolumn{7}{|c|}{ Station 09097600 Brush Creek near Collbran } \\
\hline \multirow{4}{*}{$\begin{array}{c}\text { Annual } \\
\text { exceedance } \\
\text { probability }\end{array}$} & \multirow{4}{*}{$\begin{array}{c}\text { Recurrence } \\
\text { interval } \\
\text { (years) }\end{array}$} & JRVE -- DISCI & RGES AT SELECT & XCEEDANCE P & JBABILITIES & \\
\hline & & \multicolumn{5}{|c|}{ For listed variable, estimated peak discharge, in cubic feet per second } \\
\hline & & \multirow{2}{*}{$\begin{array}{c}\text { Bulletin I7B } \\
\text { estimate }\end{array}$} & \multirow{2}{*}{$\begin{array}{l}\text { Systematic } \\
\text { record }\end{array}$} & \multirow{2}{*}{$\begin{array}{c}\text { Expected } \\
\text { probability } \\
\text { estimate }\end{array}$} & \multicolumn{2}{|c|}{$\begin{array}{l}\text { 95-percent confidence limit for } \\
\text { Bulletin I7B estimates }\end{array}$} \\
\hline & & & & & Lower & Upper \\
\hline 0.995 & 1.005 & 15.2 & 20.1 & 9.7 & 5.4 & 25.9 \\
\hline 0.99 & 1.01 & 18.0 & 22.5 & 12.8 & 7.0 & 29.6 \\
\hline 0.95 & 1.05 & 28.6 & 31.3 & 24.5 & 13.8 & 43.1 \\
\hline 0.9 & 1.11 & 36.6 & 38.1 & 33.3 & 19.8 & 53.0 \\
\hline 0.8 & 1.25 & 49.4 & 48.9 & 47.1 & 30.1 & 69.1 \\
\hline 0.5 & 2 & 87.8 & 83.5 & 87.8 & 62.1 & 124.2 \\
\hline 0.2 & 5 & 156.1 & 153.1 & 163.7 & 111.7 & 256.6 \\
\hline 0.1 & 10 & 211.0 & 216.5 & 232.0 & 145.8 & 390.7 \\
\hline 0.04 & 25 & 291.0 & 320.7 & 347.2 & 190.6 & 621.9 \\
\hline 0.02 & 50 & 358.3 & 418.6 & 462.0 & 225.4 & 844.6 \\
\hline 0.01 & 100 & 431.9 & 536.7 & 610.4 & 261.5 & $1,115.0$ \\
\hline 0.005 & 200 & 512.6 & 678.8 & 805.4 & 299.1 & $1,441.0$ \\
\hline 0.002 & 500 & 630.9 & 910.9 & -- & 351.6 & $1,969.0$ \\
\hline \multicolumn{7}{|c|}{ Non-standard values } \\
\hline 0.667 & 1.5 & 65.4 & (1.50-year flood) & Stage $=3.26 \mathrm{ft}$. & Rating table & \\
\hline 0.429 & 2.33 & 99.2 & (2.33-year flood) & Stage $=3.50 \mathrm{ft}$. & date: $10 / 01 / 1$ & \\
\hline
\end{tabular}

I N P U T D A T A S UMMAR Y

Number of peaks in record

Peaks not used in analysis

Systematic peaks in analysis

Historic peaks in analysis

Years of historic record

Generalized skew

Standard error of generalized skew

Skew option

$\begin{array}{lc}= & 12 \\ = & 0 \\ = & 12 \\ = & 0 \\ = & 0 \\ = & -0.300 \\ = & 0.550\end{array}$

$=\quad$ Weighted
NO SYSTEMATIC PEAKS WERE BELOW GAGE BASE.

NO LOW OUTLIERS BELOW FLOOD BASE WERE DROPPED.

NO HIGH OUTLIERS OR HISTORIC PEAKS EXCEEDED HHBASE.

ANNUAL FREQUENCY CURVE PARAMETERS -- LOG-PEARSON TYPE III

\begin{tabular}{lccc} 
& \multicolumn{3}{c}{ Logarithmic value } \\
\cline { 2 - 4 } & Mean & $\begin{array}{c}\text { Standard } \\
\text { deviation }\end{array}$ & Skew \\
\cline { 2 - 4 } Systematic record & 1.944 & 0.297 & 0.446 \\
Bulletin 17B estimate & 1.944 & 0.297 & 0.005
\end{tabular}

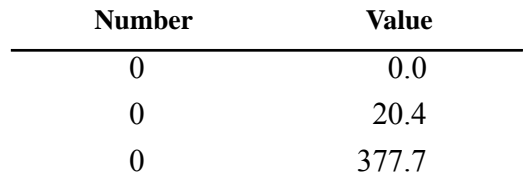

Values are in cubic feet per second

Dashes anywhere in the above data indicate value not computed.

See the file "Peaks.explanation.xls" for Bulletin

$17 \mathrm{~B}$ reference and explanation of column 


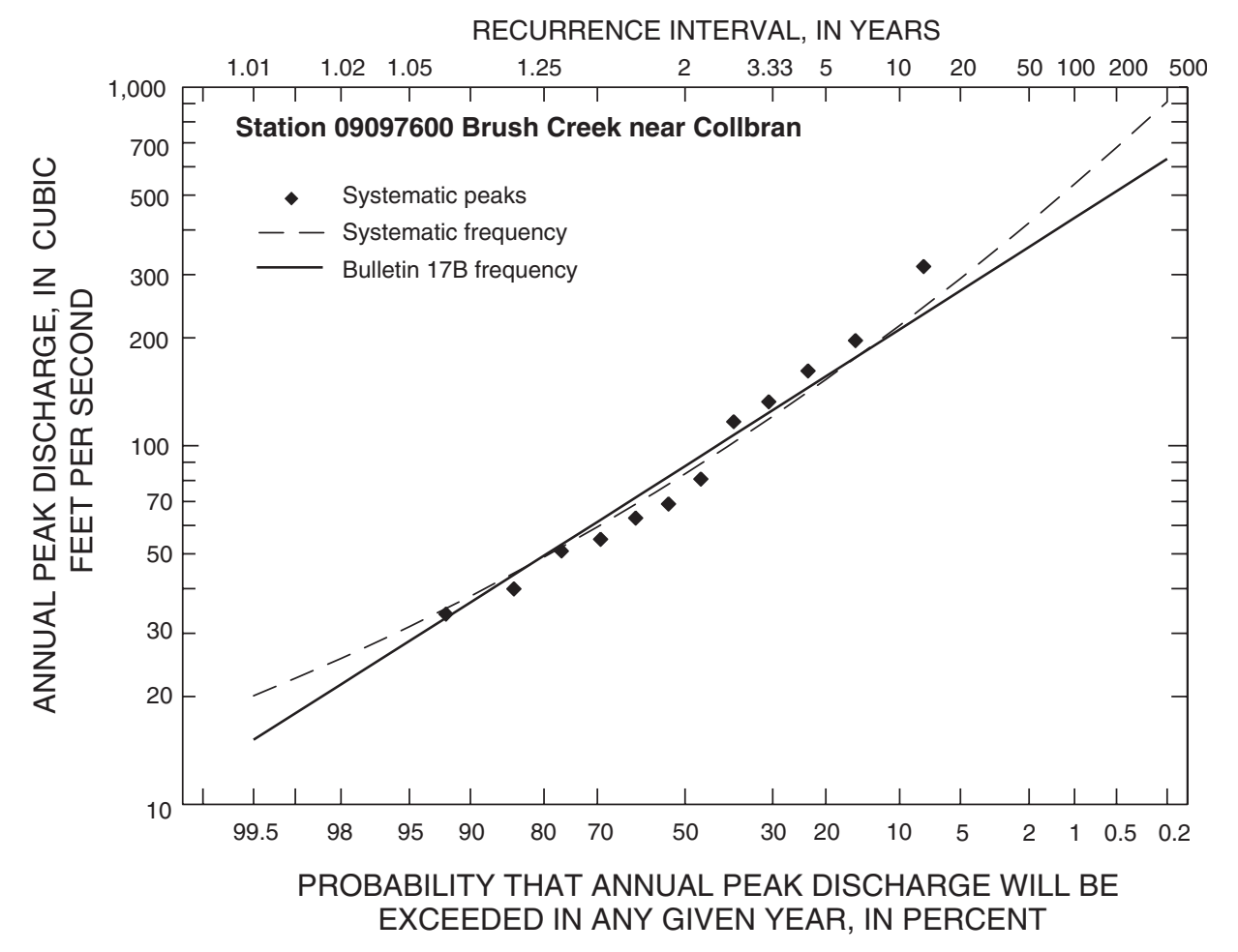

Figure 2. Example graph for results of peak frequency computation.

6 or 7 [table 4; Peak_Q.Codes.xls file in the Objective.1 (Peak.Frequency) directory of the CD-ROM]. However, peak discharge values with a peak discharge code of 6 or 7 were used in the analyses for this study because (1) peak discharge frequency analysis was needed for stations where discharge was affected by diversion or regulation (code 6) and (2) the peak discharges coded as historic (code 7) did not meet the criteria for historic peaks (U.S. Interagency Advisory Committee on Water Data, 1982; U.S. Geological Survey, 2002a [draft user manual]) even though the values were coded as being historic peaks. When using the frequency analysis results for stations where discharge is affected by diversion or regulation, the user needs to consider this fact in applying the results.

\section{Objective 2-Duration of Daily Mean Discharges on an Annual and Monthly Basis}

Flow durations for daily mean discharges were computed using the statistical analysis capabilities of the USGS National Water Information System (NWIS). Although most components of NWIS are accessible only by USGS personnel, some of the statistical procedures have been ported to software packages (such as PEAKFQ) that are available to the public. The public software program, SWSTAT (U.S. Geological Survey, 2002b), also could have been used to compute flow duration, but the use of the NWIS capability was more efficient given the number of stations and time periods in the analysis. Each Excel file for flow duration of daily mean discharge computed on an annual and monthly basis contains 13 worksheets: one worksheet for the annual computation and one worksheet for each month of the year. An example of a flow-duration data table is shown in table 5 and has the following components:

1. The station number and name.

2. A variable number of percentage values that indicate the percentage of time that a given discharge was equaled or exceeded.

3. The discharge values that correspond to the percentage values.

4. The type of discharge value; the NWIS software calculates a predetermined number of class intervals and computes percentage and discharge values for each class (the "Computed" type). Other percentage values (even values) are inter 
Table 4. Example data table for peak discharge data

\begin{tabular}{|c|c|c|c|}
\hline \multicolumn{4}{|c|}{ Station 09097600 Brush Creek near Collbran } \\
\hline \multicolumn{4}{|c|}{ Annual instantaneous peak discharges for period of record } \\
\hline $\begin{array}{l}\text { Water } \\
\text { year }\end{array}$ & Date & $\begin{array}{l}\text { Peak discharge, } \\
\text { in cubic feet } \\
\text { per second }\end{array}$ & $\begin{array}{l}\text { Peak discharge } \\
\text { code }^{1}\end{array}$ \\
\hline 1956 & $05 / 07 / 56$ & 69.0 & \\
\hline 1957 & $06 / 07 / 57$ & 317.0 & \\
\hline 1958 & $05 / 20 / 58$ & 133.0 & \\
\hline 1959 & $05 / 15 / 59$ & 51.0 & \\
\hline 1960 & $05 / 12 / 60$ & 81.0 & \\
\hline 1961 & $05 / 19 / 61$ & 55.0 & \\
\hline 1962 & $05 / 06 / 62$ & 117.0 & \\
\hline 1963 & $05 / 04 / 63$ & 34.0 & \\
\hline 1964 & $05 / 17 / 64$ & 197.0 & \\
\hline 1965 & $05 / 21 / 65$ & 162.0 & \\
\hline 1966 & $05 / 02 / 66$ & 40.0 & \\
\hline 1967 & $05 / 23 / 67$ & 63.0 & \\
\hline \multicolumn{4}{|c|}{$\begin{array}{l}{ }^{1} \text { Station } 09097600 \text { Brush Creek near Collbran does not have any peak discharge } \\
\text { s. Meaning of peak discharge codes is as follows: }\end{array}$} \\
\hline Code & \multicolumn{3}{|c|}{ Peak discharge code explanation } \\
\hline 1 & \multicolumn{3}{|c|}{ Discharge is a maximum daily mean. } \\
\hline 2 & \multicolumn{3}{|c|}{ Discharge is an estimate. } \\
\hline 3 & \multicolumn{3}{|c|}{ Discharge affected by dam failure. } \\
\hline 5 & \multicolumn{3}{|c|}{ Discharge affected by unknown degree of regulation or diversion. } \\
\hline 6 & \multicolumn{3}{|c|}{ Discharge affected by known degree of regulation or diversion. } \\
\hline 7 & \multicolumn{3}{|c|}{ Discharge is a historic peak. } \\
\hline $\mathrm{B}$ & \multicolumn{3}{|c|}{ Month or day of discharge is unknown or not exact. } \\
\hline $\mathrm{E}$ & \multicolumn{3}{|c|}{ Value is only maximum peak available for this year. } \\
\hline
\end{tabular}

polated by the NWIS software from the computed values (the "Interpolated" type).

5. A graph for the flow-duration analysis is presented to the right of the Excel data table; an example graph is shown in figure 3.

The flow-duration graph (fig. 3) consists of three hydrographs: one hydrograph shows the entire range of the flow duration and usually has a logarithmic discharge scale; a second hydrograph shows the discharge range that was equaled or exceeded 0 to 30 percent of the time; and a third hydrograph shows the discharge range that was equaled or exceeded 30 to 100 percent of the time. The second and third hydro- graphs always have an arithmetic scale for discharge; when the range of discharge is small, which includes October-March, the first hydrograph usually has an arithmetic scale also. In some cases, the second hydrograph may not include discharges at the highest percentage values ( 0 to about 3 percent). Also, sometimes the flow-duration curve is not very smooth and may be poorly defined or truncated at one end. This usually is attributable to winter discharge that is not very variable and commonly is mostly estimated, or the period of record is relatively short (table 2). An example of winter-record flow duration is shown in figure 4. 
Table 5. Example data table for results of annual and monthly flow-duration computation using daily mean discharges

\begin{tabular}{|c|c|c|}
\hline \multicolumn{3}{|c|}{$\begin{array}{l}\text { Station } 08216500 \text { Willow Creek at Creede } \\
\text { Annual flow-duration data for daily mean discharge }\end{array}$} \\
\hline $\begin{array}{l}\text { Percentage of time } \\
\text { discharge was } \\
\text { equaled or } \\
\text { exceeded }\end{array}$ & $\begin{array}{l}\text { Discharge, in cubic } \\
\text { feet per second }\end{array}$ & $\begin{array}{l}\text { Type of discharge } \\
\text { value }\end{array}$ \\
\hline 99.99 & 1.90 & Computed \\
\hline 99.56 & 2.40 & Computed \\
\hline 99.00 & 2.53 & Interpolated \\
\hline 98.00 & 2.75 & Interpolated \\
\hline 96.89 & 3.00 & Computed \\
\hline 95.00 & 3.14 & Interpolated \\
\hline 90.00 & 3.51 & Interpolated \\
\hline 87.49 & 3.70 & Computed \\
\hline 85.00 & 3.93 & Interpolated \\
\hline 80.00 & 4.39 & Interpolated \\
\hline 76.66 & 4.70 & Computed \\
\hline 75.00 & 4.87 & Interpolated \\
\hline 70.00 & 5.40 & Interpolated \\
\hline 66.12 & 5.80 & Computed \\
\hline 60.00 & 6.71 & Interpolated \\
\hline 56.07 & 7.30 & Computed \\
\hline 50.00 & 8.85 & Interpolated \\
\hline 48.61 & 9.20 & Computed \\
\hline 44.86 & 11.00 & Computed \\
\hline 40.00 & 13.26 & Interpolated \\
\hline 38.42 & 14.00 & Computed \\
\hline 31.20 & 18.00 & Computed \\
\hline 30.00 & 18.84 & Interpolated \\
\hline 25.00 & 22.35 & Interpolated \\
\hline 24.07 & 23.00 & Computed \\
\hline 20.00 & 27.91 & Interpolated \\
\hline 19.92 & 28.00 & Computed \\
\hline 16.22 & 35.00 & Computed \\
\hline 15.00 & 38.38 & Interpolated \\
\hline 12.96 & 44.00 & Computed \\
\hline 10.00 & 54.92 & Interpolated \\
\hline 9.71 & 56.00 & Computed \\
\hline 7.50 & 70.00 & Computed \\
\hline 5.35 & 87.00 & Computed \\
\hline 5.00 & 91.36 & Interpolated \\
\hline 3.58 & 109.00 & Computed \\
\hline 2.09 & 137.00 & Computed \\
\hline 2.00 & 140.98 & Interpolated \\
\hline 1.30 & 171.00 & Computed \\
\hline 1.00 & 187.69 & Interpolated \\
\hline 0.53 & 214.00 & Computed \\
\hline 0.16 & 268.00 & Computed \\
\hline 0.02 & 336.00 & Computed \\
\hline
\end{tabular}

14 Streamflow Characteristics for Selected Stations In and Near the Grand Mesa, Uncompahgre, and Gunnison National Forests, Southwestern Colorado 


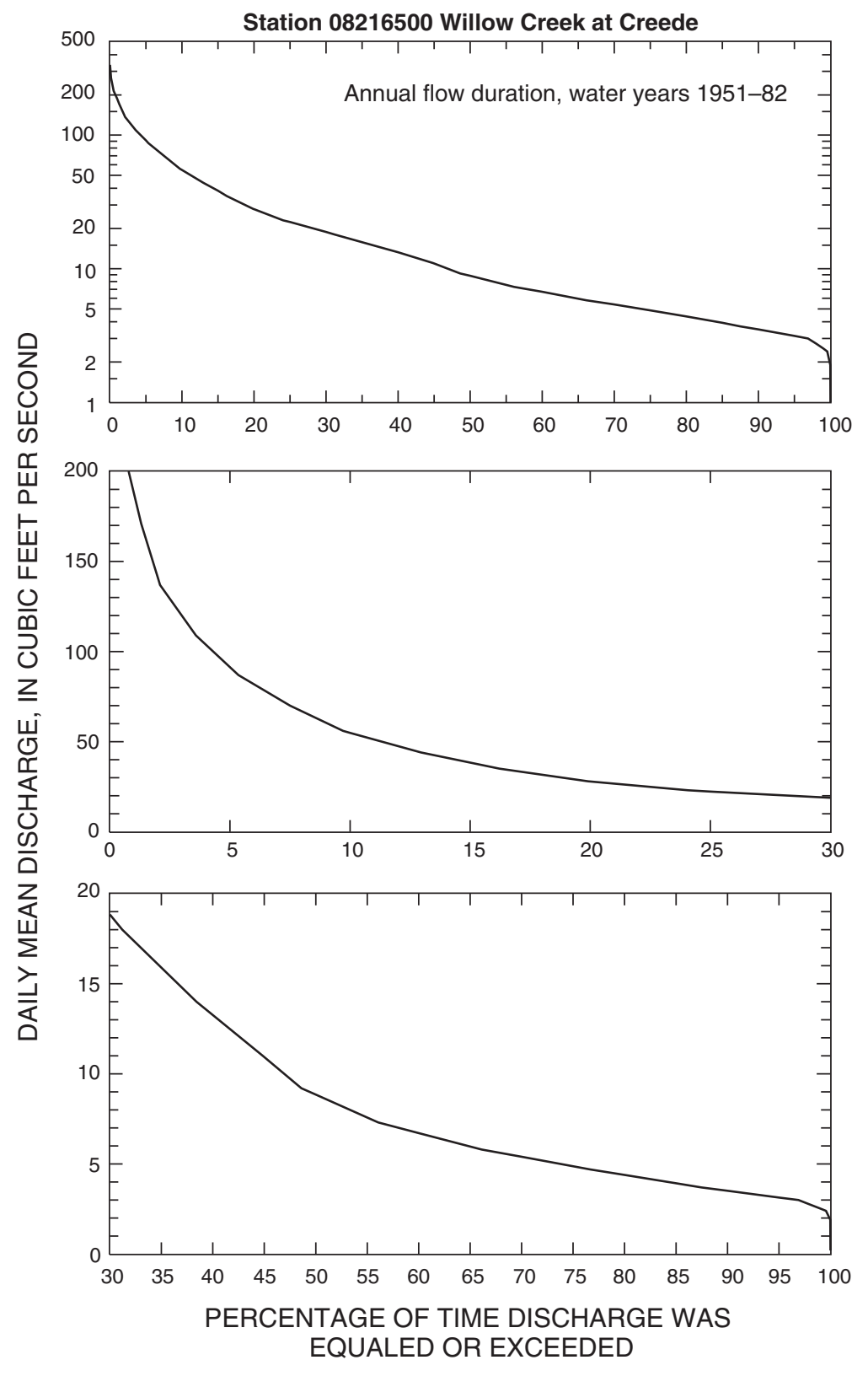

Figure 3. Example graph for results of annual and monthly flow-duration computation using daily mean discharges. 


\section{Duration of Annual and Monthly Mean Discharges}

The proposal for this study (U.S. Geological Survey, written commun., August 2000) indicated that stations with 20 years or more of record would be used in the flow-duration analysis of annual and monthly mean discharges; however, nine additional stations with 18 or 19 years of record (table 2) were included in the analysis.

The flow-duration data for annual and monthly mean discharge were computed using the univariate procedure of the Statistical Analysis System (SAS) software (SAS Institute, Inc., 1990) because the NWIS and SWSTAT programs do not readily compute flow duration of annual and monthly mean discharges due to the small number of values available for analysis. Therefore, the data tables for results of computing flow duration of annual and monthly mean discharges are somewhat different from the data tables for results of computing flow duration from daily mean discharges; however, each Excel file also has 13 worksheets for the analyses on an annual and monthly basis, and each worksheet includes a data table and a graph of the results. An example of the data table is shown in table 6 and has the following components:

1. The station number and name.

2. A uniform number of percentage values that indicate the percentage of time that a given discharge was equaled or exceeded.

3. The annual or monthly mean discharge values, in cubic feet per second, that correspond to the percentage values.

4. An additional column of annual or monthly discharge values, in acre-feet.

5. A graph showing flow duration of annual or monthly mean discharge is presented to the right of the Excel data table; an example graph is shown in figure 5.

The graph of mean annual flow duration (fig. 5) has two y-axes, one for discharge in cubic feet per second and one for discharge in acre-feet. A slight flattening of the curve can be noted at each end; this is partly attributable to the small number of data points and to the smaller variability in annual and monthly mean discharge values. The Excel data tables for monthly mean discharge are nearly the same as those for the annual mean discharge (table 6); however, the graphs for flow duration of monthly mean discharge are somewhat different (fig. 6). In this case, two hydrographs are provided, one for monthly mean discharge in cubic feet per second and one for monthly discharge in acre-feet.

\section{Objective 3-N-Day Frequency}

Computation of the N-day $(1,3,7,15,30,60$, 120 , and 183 consecutive days) high- and low-flow frequency was a 2-step process using the SWSTAT program. First, the daily mean discharges for the period of record were input and the lowest and highest mean discharges for each $\mathrm{N}$-day period in each year were computed; then, the yearly values of the N-day high- and low-flow were used in an LP3 frequency analysis.

There are two differences between the computations for N-day low flow and N-day high flow. First, the computations for high flow are made on a water year (October 1 through September 30) basis, whereas the computations for low flow are made on a climate year (April 1 through March 31) basis. Second, the high-flow frequency is expressed in terms of exceedance probability, whereas the low-flow frequency is expressed in terms of nonexceedance probability.

The first step of the analysis, computation of the highest and lowest mean discharges for each N-day period for each year, was completed for all stations except station 09174700 (table 2; seasonal record); however, the frequency analysis step was completed only for the 44 stations with 10 or more complete years of record (table 2). Because discharge records are obtained on a water year basis, the number of years of record available on a climate year basis usually will be 1 or 2 years less than the number of years available on a water year basis. Therefore, only 8 or 9 years of record were available for the low-flow frequency computation for some stations; these stations were included to be consistent with all stations used in the high-flow frequency computation. Careful judgment needs to be used in interpreting and applying the lowflow frequency results for stations with the shorter records.

\section{N-Day High-Flow Frequency}

The Excel files for the N-day high-flow frequency each contain nine worksheets. The first worksheet lists the highest mean discharge for each complete water year of record for each of the N-day periods and the rank of the $\mathrm{N}$-day discharge (table 7). 


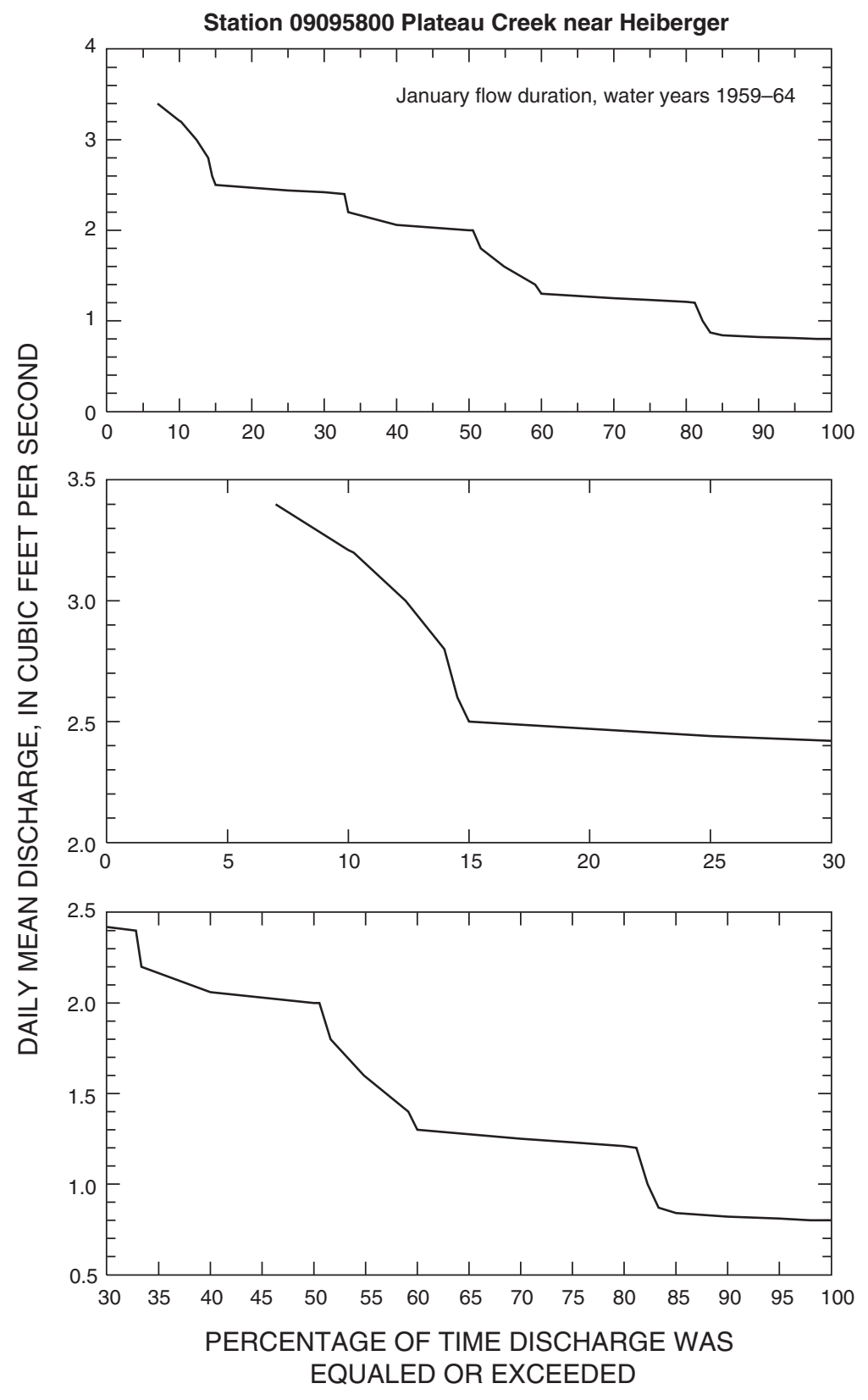

Figure 4. Example graph for results of monthly flow-duration computation during winter using daily mean discharges. 
Table 6. Example data table for results of annual and monthly flow-duration computation using annual and monthly mean discharges

\begin{tabular}{|c|c|c|}
\hline \multicolumn{3}{|c|}{$\begin{array}{l}\text { Station } 08216500 \text { Willow Creek at Creede } \\
\text { Flow-duration data for mean annual discharge }\end{array}$} \\
\hline $\begin{array}{c}\text { Percentage of } \\
\text { time discharge } \\
\text { was equaled or } \\
\text { exceeded }\end{array}$ & $\begin{array}{c}\text { Mean annual } \\
\text { discharge, in } \\
\text { cubic feet } \\
\text { per second }\end{array}$ & $\begin{array}{c}\text { Annual } \\
\text { discharge, } \\
\text { in acre-feet }\end{array}$ \\
\hline 99 & 7.71 & 5,580 \\
\hline 98 & 7.71 & 5,580 \\
\hline 97 & 7.71 & 5,580 \\
\hline 95 & 10.30 & 7,460 \\
\hline 90 & 12.10 & 8,780 \\
\hline 85 & 12.50 & 9,050 \\
\hline 80 & 13.60 & 9,850 \\
\hline 75 & 14.40 & 10,400 \\
\hline 70 & 14.90 & 10,800 \\
\hline 65 & 15.70 & 11,400 \\
\hline 60 & 16.70 & 12,100 \\
\hline 55 & 17.10 & 12,400 \\
\hline 50 & 19.50 & 14,200 \\
\hline 45 & 21.30 & 15,500 \\
\hline 40 & 23.90 & 17,400 \\
\hline 35 & 26.90 & 19,500 \\
\hline 30 & 27.30 & 19,800 \\
\hline 25 & 30.70 & 22,200 \\
\hline 20 & 31.50 & 22,900 \\
\hline 15 & 32.40 & 23,500 \\
\hline 10 & 34.20 & 24,800 \\
\hline 5 & 37.60 & 27,200 \\
\hline 3 & 39.70 & 28,700 \\
\hline 2 & 39.70 & 28,700 \\
\hline 1 & 39.70 & 28,700 \\
\hline
\end{tabular}

18 Streamflow Characteristics for Selected Stations In and Near the Grand Mesa, Uncompahgre, and Gunnison National Forests, Southwestern Colorado 


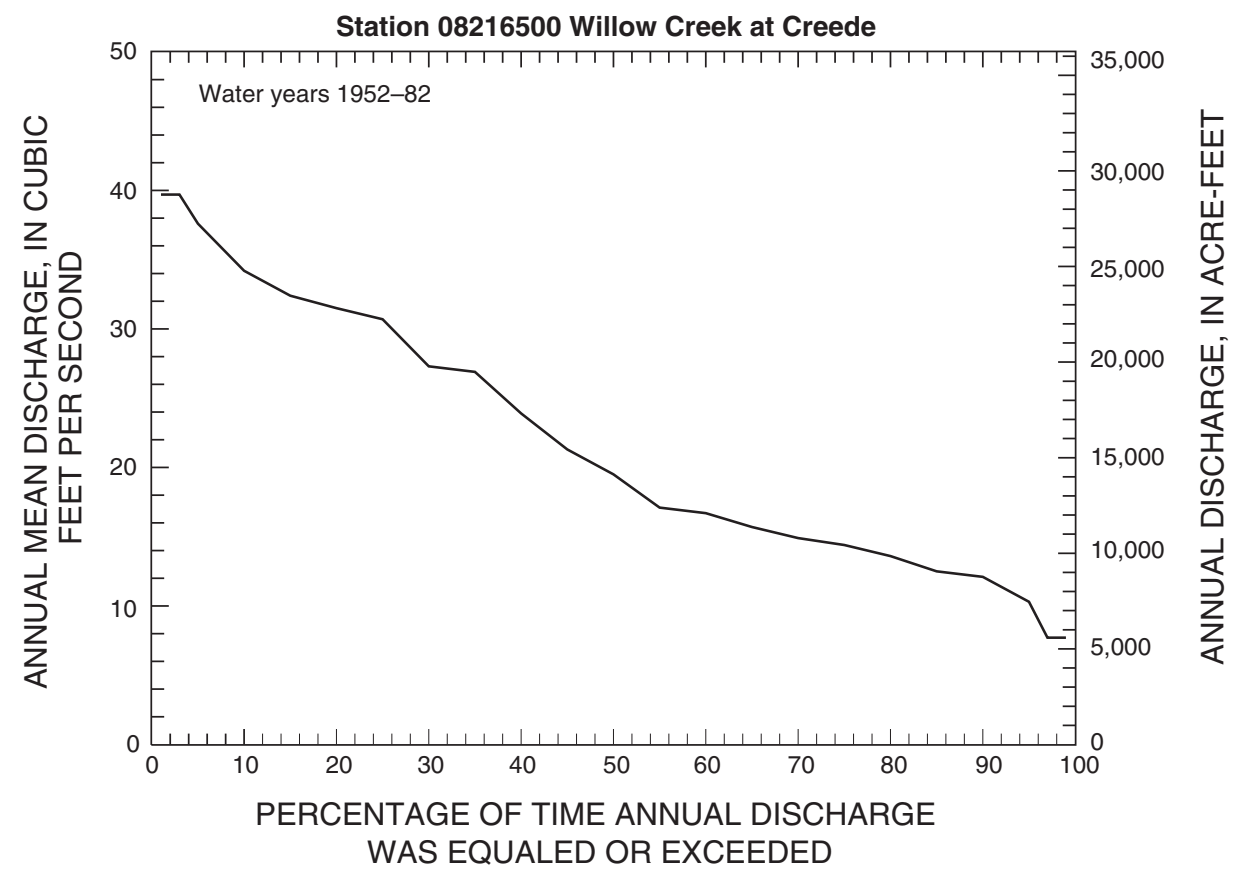

Figure 5. Example graph for results of annual flow-duration computation using annual mean discharges.

Eight additional worksheets present the high-flow frequency analysis results for each of the N-day periods; each of these eight worksheets has a data table (table 8) with the following components:

1. The station number and name and the number of days in the $\mathrm{N}$-day period.

2. A list of standard annual exceedance probabilities and recurrence intervals and the estimated N-day high-flow discharge for each listed exceedance probability and recurrence interval.

3. The statistical variables for the computed LP3 distribution including the skew, mean, and standard deviation. For the N-day frequency analysis, the skew is equal to the station skew because the LP3 enhancements in Bulletin 17B, such as weighting the skew (U.S. Interagency Advisory Committee on Water Data, 1982), are not used in the N-day frequency computations.

4. The time period and number of values used in the analysis.

5. A graph showing the LP3 frequency curve is presented to the right of the Excel data table; an example graph is shown in figure 7.

\section{N-Day Low-Flow Frequency}

The Excel files for results of the N-day lowflow frequency analysis are practically identical to those for the high-flow frequency analysis. The first worksheet lists of the lowest mean discharge for each complete climate year of record for each of the N-day periods and the rank of the N-day discharge (table 9). Eight additional worksheets present the low-flow frequency analyses results for each of the N-day periods; each of these eight worksheets has a data table (table 10) with the following components:

1. The station number and name and the number of days in the N-day period.

2. A list of standard annual nonexceedance probabilities and recurrence intervals and the estimated $\mathrm{N}$-day low-flow discharge for each listed nonexceedance probability and recurrence interval. [The additional columns that begin with "Adjusted" are described in the following paragraph.]

3. The statistical variables for the computed LP3 distribution including the skew, mean, and standard deviation. For the N-day frequency analysis, the skew is equal to the station skew because the LP3 enhancements in Bulletin 17B, such as weighting the skew (U.S. Interagency Advisory 

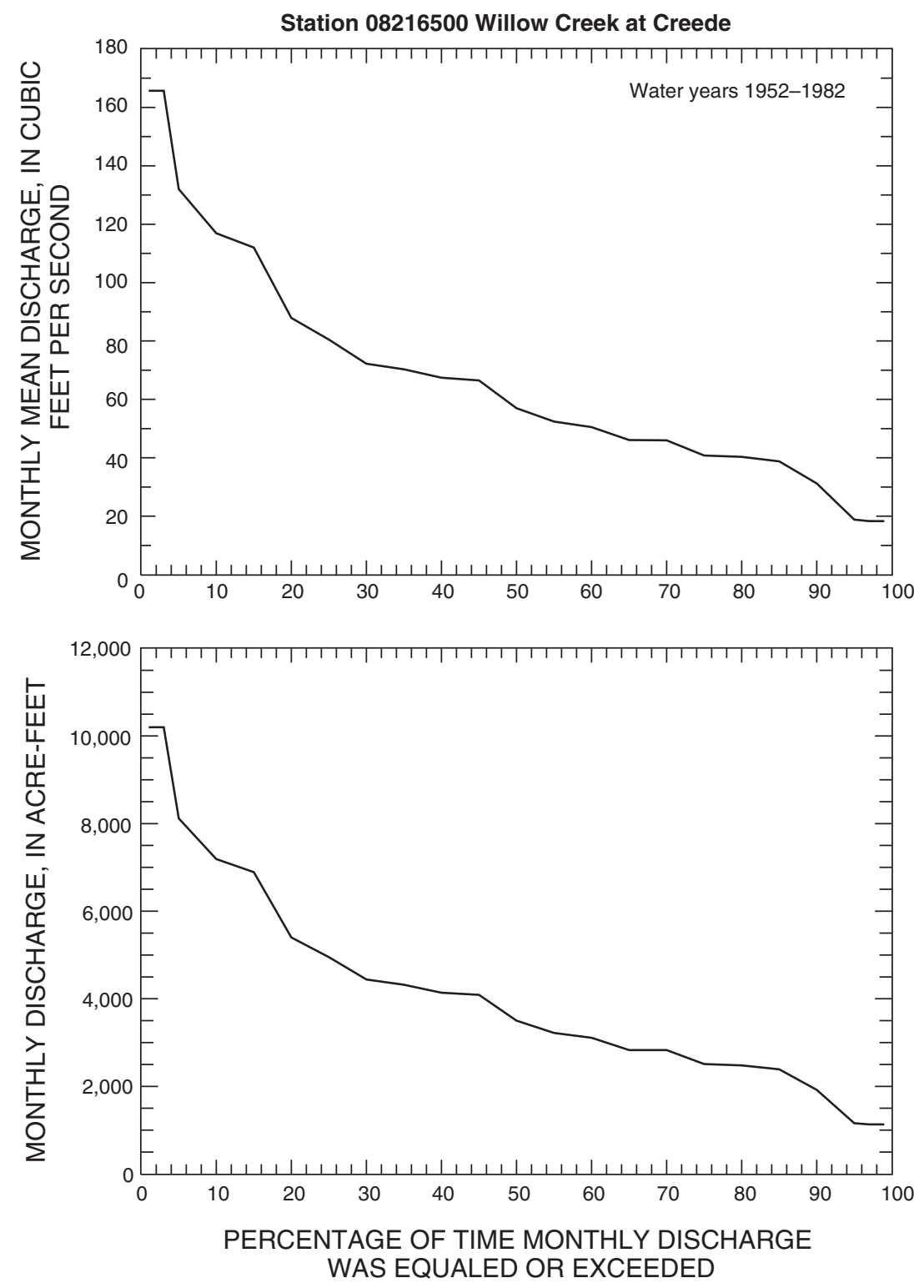

Figure 6. Example graph for results of monthly flow-duration computation using monthly mean discharges (month $=$ May). 
Table 7. Example data table for annual values of $\mathrm{N}$-day high flow used in log-Pearson type-III frequency computations

\section{Station 09096800 Buzzard Creek below Owens Creek near Heiberger}

Highest mean discharge, in cubic feet per second, and ranking for the following number of consecutive days for October to September (Water year)

\begin{tabular}{|c|c|c|c|c|c|c|c|c|c|c|c|c|c|c|c|c|}
\hline \multirow{2}{*}{$\begin{array}{c}\text { Water } \\
\text { year }\end{array}$} & \multicolumn{2}{|c|}{ 1-Day high } & \multicolumn{2}{|c|}{ 3-Day high } & \multicolumn{2}{|c|}{ 7-Day high } & \multicolumn{2}{|c|}{ 15-Day high } & \multicolumn{2}{|c|}{ 30-Day high } & \multicolumn{2}{|c|}{ 60-Day high } & \multicolumn{2}{|c|}{ 120-Day high } & \multicolumn{2}{|c|}{ 183-Day high } \\
\hline & Discharge & Rank & Discharge & Rank & Discharge & Rank & Discharge & Rank & Discharge & Rank & Discharge & Rank & Discharge & Rank & Discharge & Rank \\
\hline 1956 & 171.00 & 12 & 165.00 & 11 & 146.00 & 11 & 106.00 & 12 & 91.40 & 12 & 67.90 & 12 & 38.30 & 12 & 25.80 & 12 \\
\hline 1957 & 446.00 & 2 & 437.00 & 2 & 414.00 & 1 & 359.00 & 2 & 304.00 & 1 & 228.00 & 1 & 133.00 & 1 & 88.70 & 1 \\
\hline 1958 & 435.00 & 4 & 363.00 & 4 & 329.00 & 4 & 313.00 & 4 & 288.00 & 2 & 195.00 & 3 & 101.00 & 4 & 67.80 & 5 \\
\hline 1959 & 180.00 & 11 & 164.00 & 12 & 138.00 & 12 & 104.00 & 14 & 89.00 & 13 & 60.00 & 13 & 34.00 & 13 & 22.60 & 13 \\
\hline 1960 & 275.00 & 8 & 260.00 & 8 & 226.00 & 8 & 169.00 & 10 & 136.00 & 10 & 103.00 & 9 & 54.90 & 9 & 36.30 & 10 \\
\hline 1961 & 152.00 & 13 & 145.00 & 13 & 138.00 & 13 & 126.00 & 11 & 105.00 & 11 & 70.10 & 11 & 39.60 & 11 & 26.40 & 11 \\
\hline 1962 & 440.00 & 3 & 432.00 & 3 & 401.00 & 3 & 318.00 & 3 & 268.00 & 4 & 221.00 & 2 & 132.00 & 2 & 88.10 & 2 \\
\hline 1963 & 95.00 & 15 & 87.70 & 15 & 80.10 & 15 & 57.30 & 15 & 43.40 & 15 & 36.60 & 15 & 20.90 & 15 & 14.10 & 15 \\
\hline 1964 & 328.00 & 7 & 319.00 & 7 & 308.00 & 6 & 274.00 & 6 & 196.00 & 7 & 123.00 & 8 & 65.50 & 8 & 43.70 & 8 \\
\hline 1965 & 342.00 & 6 & 327.00 & 6 & 297.00 & 7 & 227.00 & 7 & 211.00 & 6 & 178.00 & 5 & 104.00 & 3 & 69.90 & 3 \\
\hline 1966 & 200.00 & 10 & 195.00 & 10 & 191.00 & 10 & 170.00 & 9 & 137.00 & 9 & 94.00 & 10 & 54.80 & 10 & 37.00 & 9 \\
\hline 1967 & 136.00 & 14 & 132.00 & 14 & 126.00 & 14 & 105.00 & 13 & 79.90 & 14 & 51.80 & 14 & 31.60 & 14 & 21.90 & 14 \\
\hline 1968 & 388.00 & 5 & 339.00 & 5 & 316.00 & 5 & 294.00 & 5 & 242.00 & 5 & 167.00 & 6 & 89.90 & 6 & 60.40 & 6 \\
\hline 1969 & 250.00 & 9 & 235.00 & 9 & 202.00 & 9 & 186.00 & 8 & 173.00 & 8 & 128.00 & 7 & 84.10 & 7 & 56.20 & 7 \\
\hline 1970 & 448.00 & 1 & 440.00 & 1 & 402.00 & 2 & 360.00 & 1 & 280.00 & 3 & 187.00 & 4 & 100.00 & 5 & 68.60 & 4 \\
\hline
\end{tabular}


Table 8. Example data table for results of $\mathrm{N}$-day high-flow frequency computation

\begin{tabular}{ccc}
\hline $\begin{array}{l}\text { Station 09096800 Buzzard Creek below Owens Creek near Heiberger } \\
\text { Frequency analysis results for: 1-DAY HIGH FLOW } \\
\text { Log-Pearson Type III Statistics }\end{array}$ & $\begin{array}{c}\text { Recurrence } \\
\text { interval } \\
\text { (years) }\end{array}$ & $\begin{array}{c}\text { Discharge } \\
\text { (cubic feet } \\
\text { per second) }\end{array}$ \\
\hline $\begin{array}{c}\text { Exceedance } \\
\text { probability }\end{array}$ & 1.01 & 66.9 \\
0.99 & 1.05 & 105.5 \\
0.95 & 1.11 & 132.2 \\
0.9 & 1.25 & 171.1 \\
0.8 & 2 & 267.5 \\
0.5 & 5 & 394.4 \\
0.2 & 10 & 472.6 \\
0.1 & 25 & 564.1 \\
0.04 & 50 & 627.1 \\
0.02 & 100 & 685.9 \\
0.01 & 200 & 741.2 \\
0.005 & &
\end{tabular}

The following seven statistics are based on non-zero values:

$\begin{array}{lr}\text { Mean }(\operatorname{logs}) & 2.409 \\ \text { Variance (logs) } & 0.047 \\ \text { Standard Deviation }(\operatorname{logs}) & 0.218 \\ \text { Skewness (logs) } & -0.493 \\ \text { Standard Error of Skewness (logs) } & 0.580 \\ \text { Serial Correlation Coefficient (logs) } & -0.416 \\ \text { Coefficient of Variation }(\operatorname{logs}) & 0.090\end{array}$

October 1 - start of season

September 30 - end of season

1956-1970 - time period

15 - non-zero values

0 - zero values 
Table 9. Example data table for annual values of $\mathrm{N}$-day low flow used in log-Pearson type-III frequency computation

Station 09096800 Buzzard Creek below Owens Creek near Heiberger

Lowest mean discharge, in cubic feet per second, and ranking for the following number of consecutive days for April to March (Climate year)

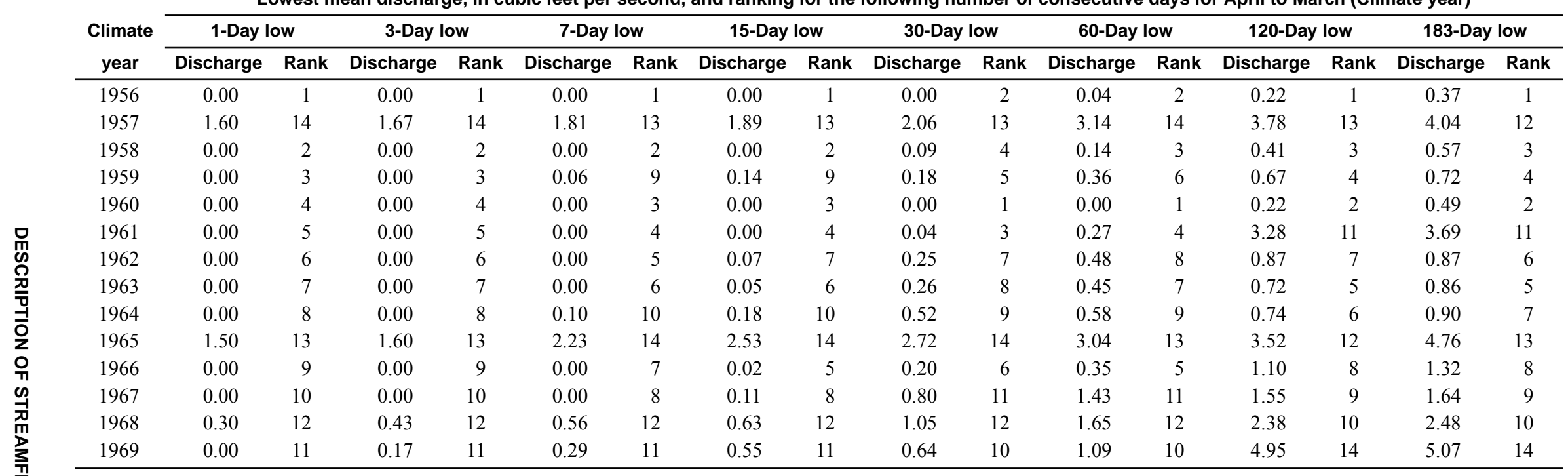

NOTE: No 1-day, 3-day, or 7-day frequency analyses for this station because of too many zero values. 
Table 10. Example data table for results of $\mathrm{N}$-day low-flow frequency computation

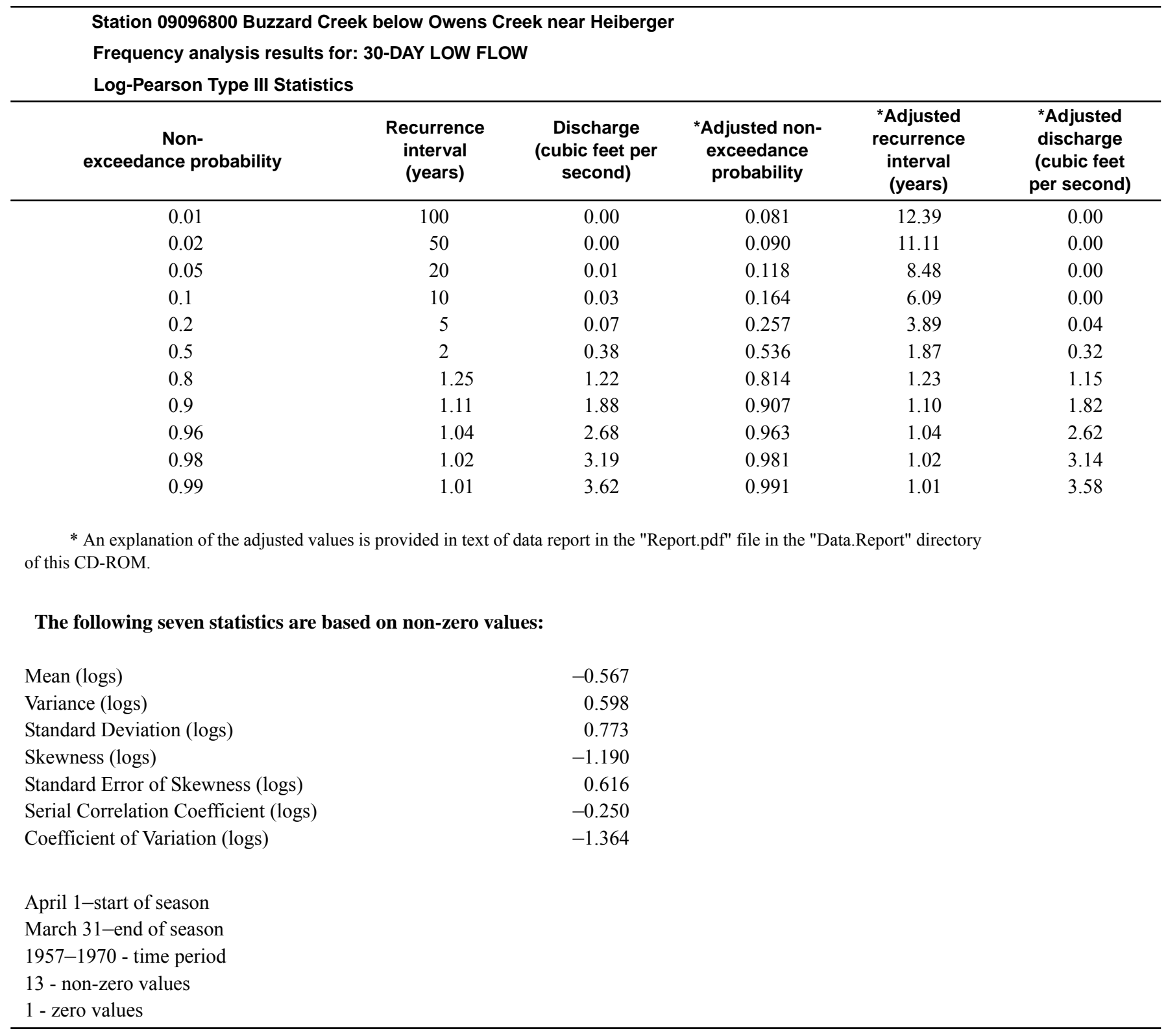

Committee on Water Data, 1982), are not used in the $\mathrm{N}$-day frequency computations.

4. The time period and number of values used in the analysis.

5. A graph showing the LP3 frequency curve presented to the right of the Excel data table; an example graph is shown in figure 8 .

There is one additional component in the data table for results of the N-day low-flow frequency analysis: The listing of the adjusted nonexceedance probabilities, recurrence intervals, and estimated N-day low- flow discharges (table 10). The additional data columns are listed only for a few stations and then only for the smaller N-day periods; the adjusted data values are needed because some of the recorded $\mathrm{N}$-day discharge values are zero. The LP3 distribution cannot be computed for a data set with zero values; therefore, the zero values are removed from the data set for the frequency computation, and then the results are adjusted to account for the values that were excluded (U.S. Geological Survey, Office of Surface Water Technical Memorandum 70.07, dated September 1969 


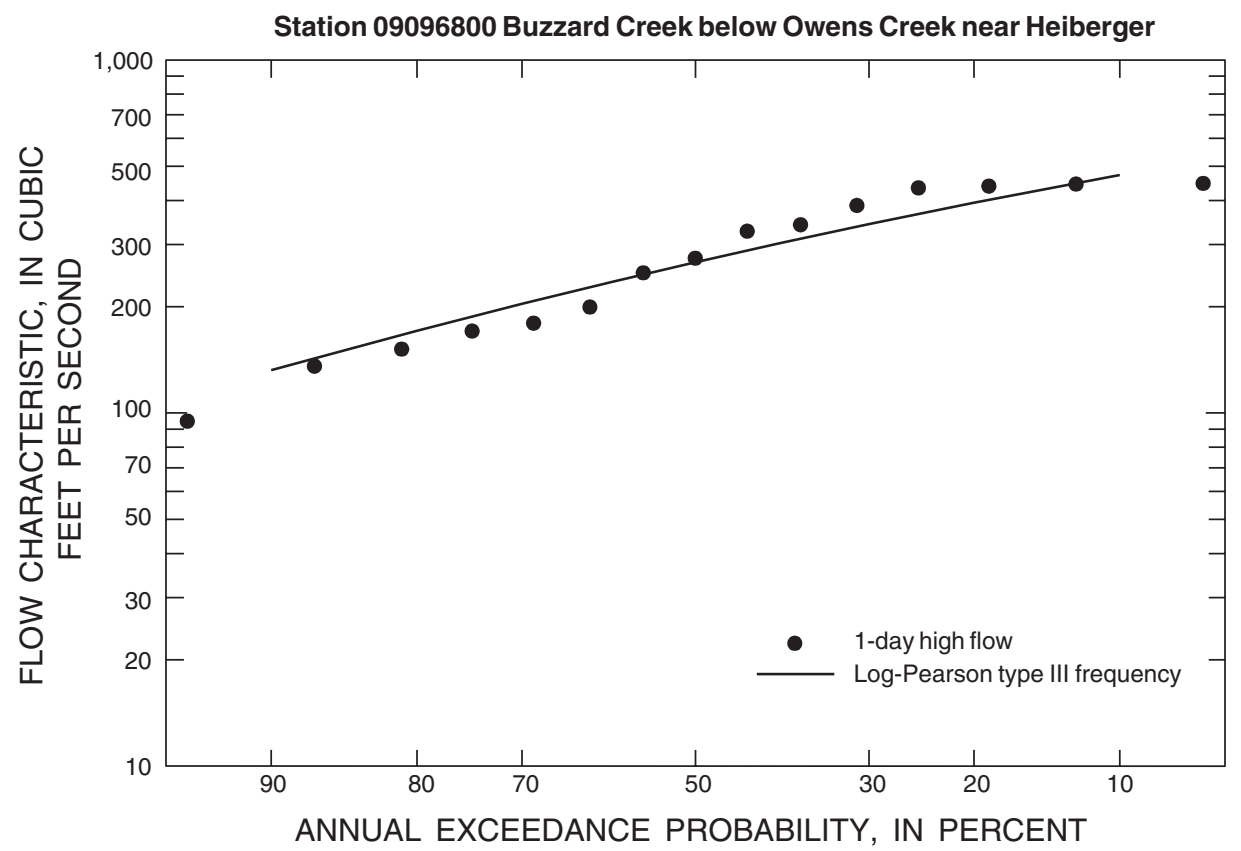

Figure 7. Example graph for results of $\mathrm{N}$-day high-flow frequency computation.

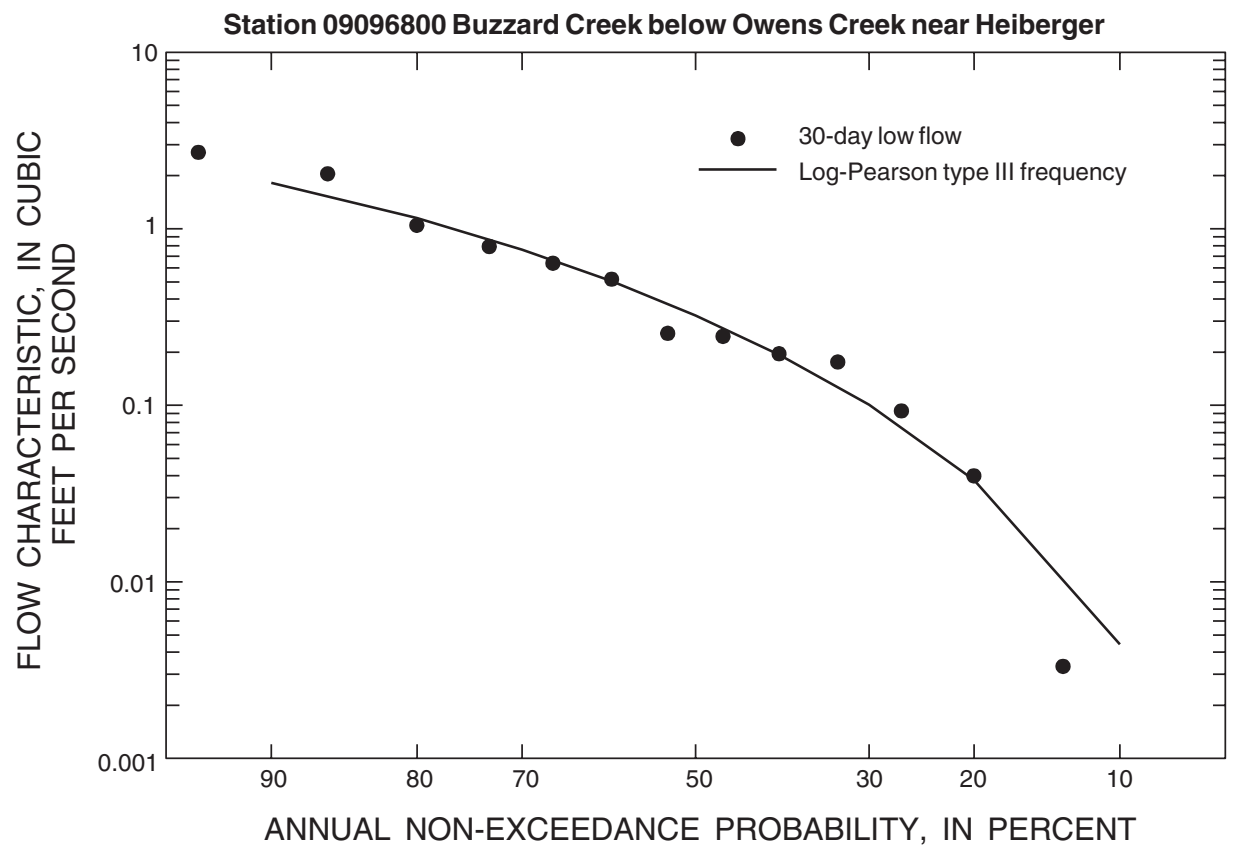

Figure 8. Example graph for results of $\mathrm{N}$-day low-flow frequency computation. 


\begin{tabular}{|c|c|c|c|c|c|c|c|c|c|c|c|c|c|}
\hline \multicolumn{14}{|c|}{ Annual and Monthly Mean Discharges, in Cubic Feet Per Second } \\
\hline $\begin{array}{l}\text { Water } \\
\text { year }\end{array}$ & Annual & October & November & December & January & February & March & April & May & June & July & August & September \\
\hline 1959 & 35.87 & 11.48 & 10.55 & 12.00 & 11.00 & 10.00 & 8.94 & 23.57 & 139.58 & 142.83 & 31.35 & 19.95 & 8.07 \\
\hline 1960 & 40.53 & 19.58 & 18.87 & 11.00 & 10.00 & 9.00 & 9.13 & 75.83 & 116.06 & 160.37 & 34.39 & 15.19 & 8.18 \\
\hline 1961 & 35.01 & 12.26 & 10.40 & 10.00 & 10.00 & 8.54 & 9.45 & 30.73 & 151.45 & 113.47 & 18.38 & 16.81 & 27.40 \\
\hline 1962 & 69.43 & 24.32 & 16.63 & 12.00 & 11.00 & 12.00 & 14.00 & 91.70 & 263.71 & 242.57 & 101.94 & 29.97 & 10.43 \\
\hline 1963 & 21.24 & 9.66 & 7.50 & 5.50 & 5.00 & 5.54 & 9.87 & 37.20 & 100.10 & 38.07 & 7.55 & 15.69 & 11.99 \\
\hline 1964 & 36.80 & 8.25 & 10.53 & 8.50 & 8.50 & 7.50 & 7.00 & 13.23 & 161.84 & 141.20 & 38.89 & 24.97 & 10.15 \\
\hline 1965 & 78.73 & 9.74 & 8.00 & 9.00 & 9.00 & 10.00 & 9.84 & 41.03 & 229.61 & 316.87 & 203.97 & 53.10 & 40.90 \\
\hline 1966 & 37.03 & 26.32 & 15.40 & 14.00 & 12.00 & 11.00 & 11.77 & 82.77 & 139.06 & 86.20 & 21.26 & 16.09 & 7.34 \\
\hline 1967 & 41.85 & 11.75 & 11.08 & 11.16 & 7.82 & 8.54 & 22.81 & 58.50 & 127.23 & 154.03 & 38.68 & 24.84 & 25.20 \\
\hline 1968 & 57.75 & 10.31 & 8.98 & 8.11 & 8.40 & 8.09 & 9.47 & 22.37 & 191.84 & 290.50 & 59.39 & 57.45 & 18.43 \\
\hline 1969 & 56.05 & 11.24 & 13.03 & 9.54 & 7.26 & 7.06 & 7.30 & 93.69 & 256.90 & 144.40 & 69.00 & 26.61 & 23.50 \\
\hline 1970 & 60.60 & 23.23 & 17.53 & 11.26 & 10.18 & 9.25 & 10.32 & 19.67 & 286.87 & 201.67 & 62.42 & 25.81 & 45.33 \\
\hline All years & 47.57 & 14.85 & 12.38 & 10.17 & 9.18 & 8.88 & 10.83 & 49.19 & 180.35 & 169.35 & 57.27 & 27.21 & 19.74 \\
\hline
\end{tabular}


Table 12. Example data table for results of annual and monthly median discharge computation

\begin{tabular}{|c|c|c|c|c|c|c|c|c|c|c|c|c|c|}
\hline \multicolumn{14}{|c|}{ Station 09113300 Ohio Creek at Baldwin } \\
\hline \multirow[b]{2}{*}{$\begin{array}{l}\text { Water } \\
\text { year }\end{array}$} & \multicolumn{13}{|c|}{ Annual and Monthly Median Discharges, in Cubic Feet Per Second } \\
\hline & Annual & October & November & December & January & February & March & April & May & June & July & August & September \\
\hline 1959 & 12.00 & 11.00 & 11.00 & 12.00 & 11.00 & 10.00 & 8.80 & 18.50 & 128.00 & 144.00 & 22.00 & 16.00 & 7.10 \\
\hline 1960 & 14.00 & 19.00 & 19.00 & 11.00 & 10.00 & 9.00 & 8.00 & 81.50 & 122.00 & 168.00 & 29.00 & 13.00 & 8.00 \\
\hline 1961 & 13.00 & 12.00 & 10.00 & 10.00 & 10.00 & 9.00 & 9.00 & 21.00 & 148.00 & 114.00 & 15.00 & 16.00 & 25.00 \\
\hline 1962 & 17.00 & 22.00 & 16.00 & 12.00 & 11.00 & 12.00 & 14.00 & 54.50 & 217.00 & 240.00 & 75.00 & 27.00 & 10.00 \\
\hline 1963 & 9.00 & 9.40 & 7.50 & 5.50 & 5.00 & 5.00 & 5.00 & 35.00 & 101.00 & 36.50 & 7.80 & 15.00 & 12.00 \\
\hline 1964 & 10.00 & 7.20 & 11.00 & 8.50 & 8.50 & 7.50 & 7.00 & 7.25 & 149.00 & 130.00 & 33.00 & 23.00 & 10.00 \\
\hline 1965 & 11.00 & 10.00 & 8.00 & 9.00 & 9.00 & 10.00 & 10.00 & 13.00 & 195.00 & 312.50 & 220.00 & 51.00 & 37.00 \\
\hline 1966 & 15.00 & 24.00 & 16.00 & 14.00 & 12.00 & 11.00 & 10.00 & 77.00 & 135.00 & 86.00 & 15.00 & 14.00 & 6.30 \\
\hline 1967 & 18.00 & 11.00 & 11.00 & 9.00 & 8.00 & 8.50 & 20.00 & 55.00 & 114.00 & 145.50 & 38.00 & 20.00 & 22.00 \\
\hline 1968 & 14.50 & 9.20 & 9.00 & 8.00 & 8.50 & 8.00 & 8.50 & 22.00 & 128.00 & 305.00 & 59.00 & 55.00 & 18.00 \\
\hline 1969 & 15.00 & 11.00 & 13.00 & 9.80 & 7.20 & 7.10 & 7.40 & 57.50 & 254.00 & 130.00 & 65.00 & 26.00 & 24.00 \\
\hline 1970 & 21.00 & 23.00 & 17.00 & 11.00 & 10.00 & 9.50 & 10.00 & 14.00 & 301.00 & 209.00 & 57.00 & 24.00 & 33.00 \\
\hline All years & 14.25 & 11.00 & 11.00 & 9.90 & 9.50 & 9.00 & 8.90 & 28.50 & 141.50 & 144.75 & 35.50 & 21.50 & 15.00 \\
\hline
\end{tabular}

Note: Median value for all years is the median of the annual or monthly values for individual years. 
Table 13. Example data table for results of frequency computation using annual and monthly mean discharges

\begin{tabular}{ccc}
\hline $\begin{array}{c}\text { Station 09113300 Ohio Creek at Baldwin } \\
\text { Frequency-Curve Data for May }\end{array}$ \\
\hline $\begin{array}{c}\text { Annual } \\
\text { exceedance } \\
\text { probability }\end{array}$ & $\begin{array}{c}\text { Recurrence } \\
\text { interval } \\
\text { (years) }\end{array}$ & $\begin{array}{c}\text { May mean } \\
\text { discharge, in } \\
\text { cubic feet } \\
\text { per second }\end{array}$ \\
\hline 0.995 & 1.005 & 73.4 \\
0.99 & 1.01 & 79.1 \\
0.95 & 1.05 & 97.6 \\
0.9 & 1.11 & 109.7 \\
0.8 & 1.25 & 126.6 \\
0.5 & 2 & 168.7 \\
0.2 & 5 & 228.0 \\
0.1 & 10 & 268.6 \\
0.04 & 25 & 321.2 \\
0.02 & 50 & 361.5 \\
0.01 & 100 & 402.8 \\
0.005 & 200 & 445.3 \\
FREQUENCY CURVE PARAMETERS-LOG-PEARSON TYPE III
\end{tabular}

FREQUENCY CURVE PARAMETERS-LOG-PEARSON TYPE III

\begin{tabular}{lccc} 
& \multicolumn{3}{c}{ Logarithmic value } \\
\cline { 2 - 4 } Systematic record & Mean & $\begin{array}{l}\text { Standard } \\
\text { deviation }\end{array}$ & Skew \\
\cline { 2 - 4 } & 2.232 & 0.152 & 0.179 \\
\hline
\end{tabular}

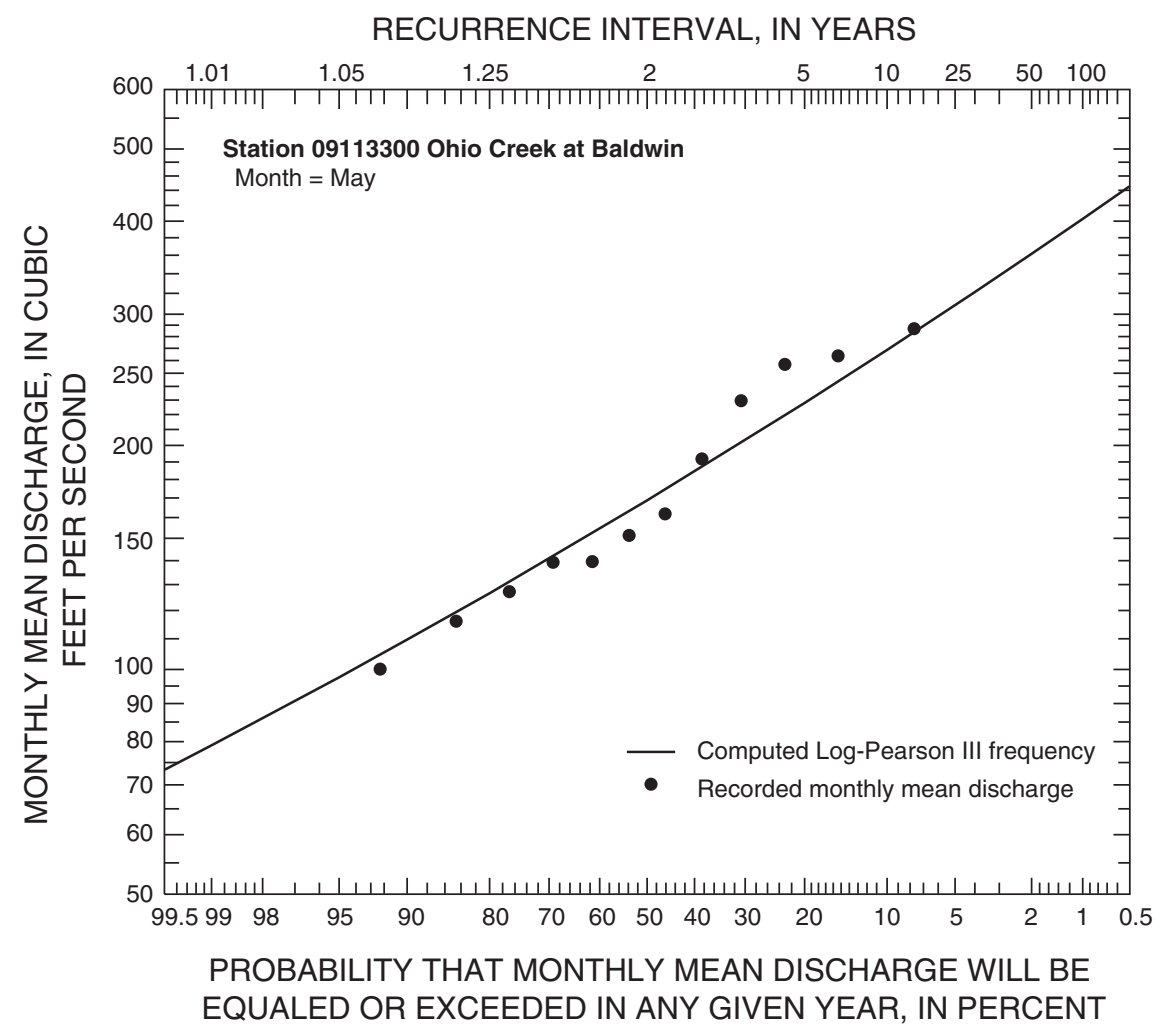

Figure 9. Example graph for results of frequency computation using annual and monthly mean discharges. 
and accessed May 10, 2002, at URL

http://water.usgs.gov/admin/memo/SW/sw70.07.html). The adjustment for zero discharges in the frequency analysis has the greatest effect on estimated discharges for the smallest nonexceedance probabilities (table 10).

\section{Objective 4-Mean and Median Discharge on an Annual and Monthly Basis}

The annual and monthly mean and median discharges also were computed from daily mean discharges by using the univariate procedure of the SAS software (SAS Institute, Inc., 1990). The statistics were computed only for years and months with complete daily discharge record. Examples of the data tables provided in the Excel files are shown in tables 11 and 12 . The annual and monthly mean and median discharges for all years in the data tables (last row, tables 11 and 12) are the mean and median of the annual and monthly values for the individual years. In the case of mean, the annual and monthly means for all years are about equal to the annual and monthly means computed from daily mean discharges; however, in the case of median, the annual and monthly medians for all years usually are not about equal to the annual and monthly medians computed from daily mean discharges.

\section{Frequency of Annual and Monthly Mean and Median Discharges}

Frequency analysis of the annual and monthly mean and median discharges was completed using the PEAKFQ program with the options that enabled a simple LP3 frequency analysis without the enhancements described in Bulletin 17B (U.S. Interagency Advisory Committee on Water Data, 1982). The PEAKFQ program was used instead of the SWSTAT program because PEAKFQ provides a simpler method of data handling. Low-outlier criteria were used; the criteria were computed by the PEAKFQ program for each individual station based on the available input data.

\section{Annual and Monthly Mean}

Each Excel file showing results for flow duration of daily mean discharge computed on an annual and monthly basis contains 13 worksheets: one worksheet is for the annual computation and twelve work- sheets are for each month of the year. An example of the data table for frequency computation of annual and monthly mean discharges is shown in table 13 and contains the following components:

1. The station number and name.

2. A list of standard annual exceedance probabilities and recurrence intervals and the estimated annual or monthly mean discharges for each listed exceedance probability and recurrence interval.

3. The computed parameters, in logarithmic units, for the LP3 distribution; these results exclude any low outliers.

4. A graph showing the LP3 frequency curve is presented to the right of the Excel data table; an example graph is shown in figure 9.

\section{Annual and Monthly Median}

Each Excel file showing results for flow duration of daily mean discharge computed on an annual and monthly basis contains 13 worksheets: One worksheet for the annual computation and one worksheet for each month of the year. An example of the data table for frequency computation of annual and monthly median discharges is shown in table 14 and contains the following components:

1. The station number and name.

2. A list of standard annual exceedance probabilities and recurrence intervals and the estimated annual or monthly median discharges for each listed exceedance probability and recurrence interval.

3. The computed parameters, in logarithmic units, for the LP3 distribution; these results exclude any low outliers.

4. A graph showing the LP3 frequency curve presented to the right of the Excel data table; an example graph is shown in figure 10 .

The example for frequency of annual and monthly median discharge is intended to show the effect of low outliers in the analysis. When low outliers are removed from a data set, a conditional probability adjustment needs to be applied (U.S. Interagency Advisory Committee on Water Data, 1982, p. 17-19, Appendix 5); this adjustment is similar to the adjustment made to the $\mathrm{N}$-day low-flow frequency when zero discharges were in the record. The resulting outputs from the PEAKFQ and SWSTAT programs, however, are somewhat different. The output data (table 14) and frequency curve (fig. 10) reflect the conditional probability adjustment. 
Table 14. Example data table for results of frequency computation using annual and monthly median discharges

\begin{tabular}{ccc}
\hline $\begin{array}{c}\text { Station 09113300 Ohio Creek at Baldwin } \\
\text { Frequency Curve Data for December Median Discharge }\end{array}$ \\
\hline $\begin{array}{c}\text { Annual } \\
\text { exceedance } \\
\text { probability }\end{array}$ & $\begin{array}{c}\text { Recurrence } \\
\text { interval } \\
\text { (years) }\end{array}$ & $\begin{array}{c}\text { December } \\
\text { mean } \\
\text { discharge, in } \\
\text { cubic feet } \\
\text { per second }\end{array}$ \\
\hline 0.995 & 1.005 & -- \\
0.99 & 1.01 & -- \\
0.95 & 1.05 & -- \\
0.9 & 1.11 & 8.0 \\
0.8 & 1.25 & 8.6 \\
0.5 & 2 & 10.0 \\
0.2 & 5 & 11.7 \\
0.1 & 10 & 12.7 \\
0.04 & 25 & 13.9 \\
0.02 & 50 & 14.8 \\
0.01 & 100 & 15.7 \\
0.005 & 200 & 16.6
\end{tabular}

FREQUENCY CURVE PARAMETERS-LOG-PEARSON TYPE III

Logarithmic value

\begin{tabular}{lccc} 
& Mean & deviation & Skew \\
\cline { 2 - 4 } Systematic record & 1.002 & 0.078 & 0.223
\end{tabular}

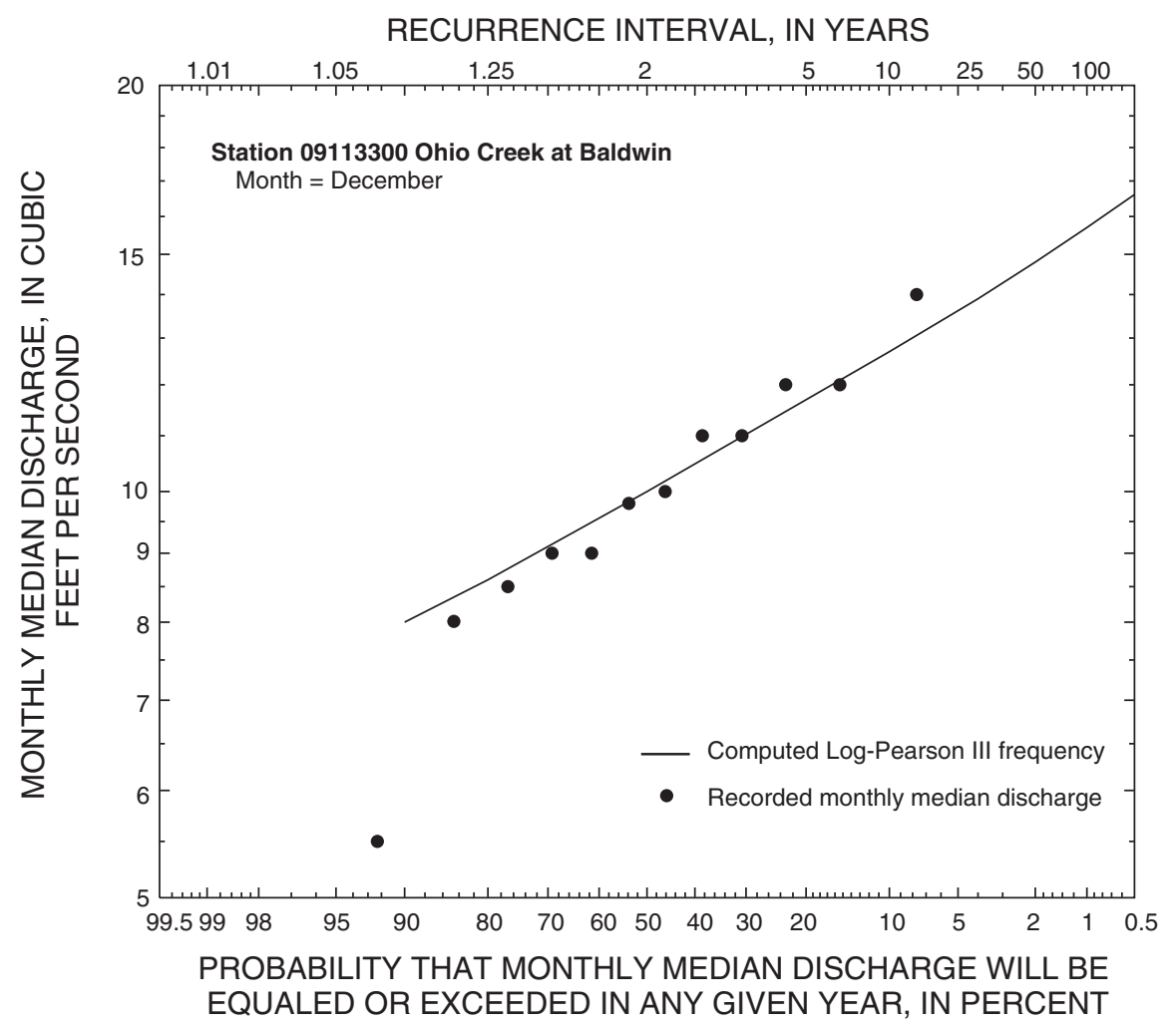

Figure 10. Example graph for results of frequency computation using annual and monthly median discharges.

30 Streamflow Characteristics for Selected Stations In and Near the Grand Mesa, Uncompahgre, and Gunnison National Forests, Southwestern Colorado 


\section{SUMMARY}

The Land and Resources Management Plan (LRMP) for the Grand Mesa, Uncompahgre, and Gunnison National Forests (study area) in Colorado was completed in 1983 and was substantially revised in 1991. Since completion of the 1983 LRMP, the study area has experienced increases in population growth and development of private land, increases in recreational use, and changes in the demand and use of natural resources. Because the LRMP has not been revised for a number of years and because of the changes in resource knowledge and use, the Grand Mesa, Uncompahgre, and Gunnison National Forests are in the process of revising their LRMP.

The Grand Mesa, Uncompahgre, and Gunnison National Forests managers have identified a need for (1) scientifically based streamflow data to support instream flow analysis that is acceptable to all interested parties and (2) an analysis of streamflow data in order to describe and understand the seasonal and annual variability. To provide the needed streamflow data and analysis, the U.S Geological Survey (USGS), in cooperation with the Grand Mesa, Uncompahgre, and Gunnison National Forests, began a study in 2000 to develop selected streamflow characteristics for streamflow-gaging stations in and near the study area.

The purpose of this report is to present the compiled daily, monthly, and annual mean discharge data for 60 stations from the beginning of available daily discharge data through water year 2000 and results for the following computed streamflow characteristics:

1. Instantaneous peak-flow frequency computed for 45 stations using the log-Pearson type III (LP3) distribution. The results include the annual instantaneous peak discharges that have a 1.5and 2.33-year recurrence interval along with the corresponding stages (gage-heights) taken from the most recent or last rating curve in use.

2. Flow duration computed for daily mean discharges on (a) an annual (water year) basis and (b) a monthly basis; these analyses were made for all 60 stations. Additional results include flow duration computed for annual and monthly mean discharges for 28 stations.

3. N-day low-flow and high-flow frequency computed for daily mean discharges using the LP3 distribution; these analyses were made for $1,3,7,15$,
$30,60,120$, and 183 consecutive days and for 43 stations.

4. Annual and monthly mean and median discharges for each year and month of record computed from the daily mean discharge data; these analyses were performed for all 60 stations. In addition, results for frequency of the annual and monthly mean and median annual discharges computed for 43 stations using the LP3 distribution.

The study area is located in southwestern Colorado within the Gunnison River, Dolores River, and Plateau Creek Basins, which are tributaries of the Colorado River. The area comprises about 12,890 $\mathrm{mi}^{2}$ within the three drainage basins; however, the area within the Grand Mesa, Uncompahgre, and Gunnison National Forests is only about $4,940 \mathrm{mi}^{2}$ (about $3,161,600$ acres). Elevations range from about $4,600 \mathrm{ft}$ at Grand Junction to about $14,000 \mathrm{ft}$ at several mountain peaks near Lake City and Ouray. The large range in elevation and presence of numerous mountain ranges have a profound effect on precipitation, which ranges from about 8 inches per year at Grand Junction to about 40 inches per year in mountains along the Continental Divide. Winter precipitation results in accumulation of mountain snowpacks with 10 to 25 inches of water equivalent; melting of the snowpack during April through July results in about 50 to 80 percent of the annual streamflow.

The cooperative study with the Grand Mesa, Uncompahgre, and Gunnison National Forests required that results of the streamflow characteristics analyses be provided in digital (computerized) format; hence, all discharge data and results from the four study objectives are presented in Microsoft Excel workbooks (Excel files) on the enclosed CD-ROM. Data on the CD-ROM are arranged in a directory structure based on the four report purposes (study objectives).

\section{REFERENCES}

Chaney, T.H., Kuhn, Gerhard, Brooks, Tom, and others, 1987, Hydrology of Area 58, Northern Great Plains and Rocky Mountain coal provinces, Colorado and Utah: U.S. Geological Survey Water-Resources Investigations/Open-File Report 85-479, 103 p. 
Clayton, B.S., 1912, The flood of October 5, 1911, in southwestern Colorado: Denver, Colorado State Engineer, Sixteenth Biennial Report, chap. XI, p. 127-129.

Colorado Climate Center, compiler, 1984, Colorado average annual precipitation, 1951-1980: Reston, Va., U.S. Geological Survey, 1 sheet, scale 1:500,000.

Federal Register, 1999, Revised land and resource management plan, Grand Mesa, Uncompahgre, and Gunnison National Forests, CO: Federal Register, September 28, 1999 , v. 64 , no. 187 , p. 52266-52273.

Fenneman, N.M., 1931, Physiography of western United States: New York, McGraw-Hill, 534 p.

Kuhn, Gerhard, and Nickless, R.C., 1994, Use of frequency analysis and the extended streamflow prediction procedure to estimate evacuation dates for the joint-use pool of Pueblo Reservoir, Colorado: U.S. Geological Survey Water-Resources Investigations Report 944054, $46 \mathrm{p}$.

Rantz, S.E., and others, 1982a, Measurement and computation of streamflow-Volume 1, measurement of stage and discharge: U.S. Geological Survey Water-Supply Paper 2175, p. 1-284.

1982b, Measurement and computation of streamflow-Volume 2, computation of discharge: U.S. Geological Survey Water-Supply Paper 2175, p. 285631.

Richter, B.D., Kircher, J.E., Remmers, M.A., and Forst, B.A., 1984, Summary of basin and streamflow characteristics for selected basins in western Colorado and adjacent States: U.S. Geological Survey Open-File Report 84-137, 266 p.

SAS Institute, Inc., 1990, SAS procedures guide, version 6, third edition: Cary, N.C., SAS Institute Inc., 705 p.
U.S. Department of Agriculture, 2002a, About the NEPA/NFMA homepage: USDA Forest Service NEPA, NFMA and Appeals, accessed May 10, 2002, at URL http://www.fs.fed.us/forum/ nepa/aboutnepanfma.html.

U.S. Department of Agriculture, 2002b, Forest planning on the Grand Mesa, Uncompahgre, and Gunnison National Forests: Grand Mesa, Uncompahgre and Gunnison National Forests homepage, accessed May 10, 2002, at URL http:/www.fs.fed.us/r2/ gmug/policy/plan_rev/index.shtml.

U.S. Department of Agriculture, 2002c, National Forest Management Act of 1976: Forest Service, accessed May 10, 2002, at URL http://www.fs.fed.us/forum/nepa/nfmalaw.html.

U.S. Environmental Protection Agency, 2002, National Environmental Policy Act: Office of Federal Activities, accessed May 10, 2002, at URL http://ceq.ch.doc.gov/nepa/regs/nepa/nepacquia.htm.

U.S. Geological Survey, 2002a, PEAKFQ_Floodfrequency analysis based on Bulletin 17B: U.S. Geological Survey Water Resources Applications Software, accessed May 13, 2002, at URL http://water.usgs.gov/software/peakfq.html.

U.S. Geological Survey, 2002b, SWSTAT_-Surface-water statistics: U.S. Geological Survey Water Resources Applications Software, accessed May 13, 2002, at URL http://water.usgs.gov/software/swstat.html.

U.S. Interagency Advisory Committee on Water Data, 1982, Guidelines for determining flood flow frequency: Hydrology Subcommittee, Bulletin 17B, 28 p., 14 apps. [Available from the National Technical Information Service as report PB-86-157278/AS] 